\title{
Mimari Mirasın Sel Riski Analizi İçin Bir Model Önerisi: Edirne II. Bayezid Külliyesi Sel Riski Analizi
}

\author{
A Model Proposal for the Flood Risk Analysis of the Architectural Heritage: \\ Edirne Bayezid II Complex Flood Risk Analysis
}

\author{
(D) Banu GÖKMEN ERDOĞAN, ${ }^{1}$ (1) Zeynep GÜL ÜNAL²
}

\section{EXTENDED ABSTRACT}

According to the climate change projections, there will be an increase in torrential rains and related floods. In parallel with this, the risk of flood damage to the architectural heritage will increase in the future. Floods cause serious damage to the architectural heritage. Since flood risk analyses are generally made basin-based, studies on flood risks of cities are still inadequate. Therefore, flood risks arising from the architectural heritage's own characteristics and its current situations are not known. Not knowing which architectural heritage poses the flood risk and its potential losses increase the damage. In preventive preservation, the measures taken before the risks occur are effective in reducing the damage, even if they do not eliminate the risks completely. It is necessary to know the flood risk in order to make the architectural heritage be prepared against floods that are predicted to increase with the effect of climate change. This study is aimed to develop a model for analysing the flood risk of architectural heritage. With the Architectural Heritage Flood Risk Analysis Model (MISRAM) developed in line with this purpose, the vulnerability of any architectural heritage can be calculated with the parameter scores developed over the building's own characteristics and current state. The development and implementation of the model were carried out in 4 stages. In the first stage: flood damage in the architectural heritage has been investigated. On-site detection, observation, and investigations were made to determine the factors that increase the damage. Flood-induced forces and effects from the data obtained. The types of damage caused by these forces and effects in the architectural heritage, the areas where the damage occurred in the building and the possible damage risks were determined. In the second stage: the factors affecting the damage level were defined and transformed into flood risk parameters. In the third stage: the flood risk parameters and the coefficient of flood risk area were made into a calculation table in an Excel program. The analyse form was created by adding the building identification section to the created calculation sheet. In the fourth stage: the risk analysis forms were filled in on-site.

As a result of the researches made in the scope of the study's problem, the findings below have been reached:

- Climate change causes an increase in sudden and heavy rains and accordingly flash floods, and these effects will continue to increase in the future.

- Architectural heritage located in the region with the same flood risk coefficient may have different flood risk levels depending on different parameters. Therefore, the flood risk of the architectural heritage cannot be calculated only through the flood risk of the region where it is located, a heritage-specific risk analysis model should be developed and in this model, the heritage's own characteristics and current situation should be taken into account.

- Factors that increase flood damage in architectural heritage should be identified and included in the calculation in risk analysis.

- There has been an increase in the number of floods in the province of Edirne after the 2000s.

The developed model proposal MISRAM was applied to the buildings of Bayezid II Complex, and the flood risk levels of the buildings were determined. Determining the flood risk level in the flood management planning of the architectural heritage is the first step and constitutes important data for decision-makers. In further studies, it is recommended to develop protection measures and interventions that will not adversely affect the heritage values for the architectural heritage whose flood risk level is determined, and to analyse the flood risk of the cultural heritage other than the architectural heritage. The flood risk of the architectural heritage can be analysed and appropriate flood prevention and response decisions can be made via applying MISRAM. It can be integrated into disaster management plans of local governments, and it may constitute the first step in reducing architectural heritage damages and preventing losses in flood disasters. MISRAM is a method that can be used both as a resource for creating architectural heritage flood risk maps and for decision-makers to take appropriate measures and intervention decisions.

Keywords: Architectural heritage flood risk analysis; climate change; Edirne Bayezid II Complex; flood hazard on architectural heritage.

Bu makale, Yıldız Teknik Üniversitesi Fen Bilimleri Enstitüsü Mimarlık Anabilim Dalı, Rölöve ve Restorasyon Programı́nda Prof. Dr. Zeynep Gül Ünal danışmanlığında devam eden Banu Gökmen Erdoğan'ın doktora tez çalışması kapsamında üretilmiştir.

'Trakya Üniversitesi Mimarlık Fakültesi, Mimarlık Bölümü, Edirne ${ }^{2} Y ı l d ı z$ Teknik Üniversitesi Mimarlık Fakültesi, Mimarlık Bölümü, İstanbul

Başvuru tarihi: 06 Nisan 2021 - Kabul tarihi: 06 Ağustos 2021

İletişim: Banu GÖKMEN ERDOĞAN. e-posta: banugerdogan@trakya.edu.tr

○ 2021 Yıldız Teknik Üniversitesi Mimarlık Fakültesi - ๑ 2021 Yıldız Technical University, Faculty of Architecture 
İklim değişikliği projeksiyonlarına göre, gelecekte Türkiye'nin de içerisinde bulunduğu iklim kuşağında, şiddetli yağış ve ani selde artış olacaktır. Sel, mimari mirasta çok ciddi hasarlara neden olmaktadır. Önleyici korumada riskler ortaya çıkmadan önce alınan önlemler, riskleri ortadan kaldırmasa da hasarı azaltmada etkilidir. Riskler bilinmeden risklere karşı hazırıklı olmak mümkün değildir. İklim değişikliği etkisiyle artacağı öngörülen sellere karşı mimari mirasın da hazırlıklı hale getirilmesi için sel riskinin bilinmesi çok önemlidir. Bu nedenle bu çalışmada mimari mirasın sel riskini analiz etmeye yönelik bir model geliştirilmesi amaçlanmıştır. Bu doğrultuda mimari mirasın sel kaynaklı hasarları araştııılmış; hasarı artıran faktörlerin belirlenmesi için yerinde tespit, gözlem ve incelemeler yapılmış; tarihi sellere yönelik arşiv ve literatür taranmıştır. Elde edilen verilerden sel kaynaklı kuvvetler ve etkiler; bu kuvvet ve etkilerin mimari mirasta oluşturduğu hasar türleri, yapıda hasarların oluştuğu bölgeler ve olası hasar riskleri belirlenmiştir. Hasar düzeyini etkileyen faktörler tanımlanarak sel risk parametrelerine dönüştürülmüş ve her risk parametresi kendi içerisinde risk oluşturma düzeyine göre derecelendirilmiştir. Sel riskli alan katsayısının belirlenmesi için örneklem alanının sel risk haritaları ile geçmiş sel yayılım alanları ArcGıS programında çakıştııımış ve sel riskli alan sınırları işaretlenmiştir. Sel risk parametreleri ve sel riskli alan katsayısı Excel programında hesaplama tablosu haline getirilmiş ve tabloya yapı künyesi kısmı eklenerek "Mimari Miras Sel Riski Analiz Formu” oluşturulmuş ve örneklem alan yapılarının bilgileri bu formlara yerinde gözlemle işlenmiştir. Geliştirilen model MISRAM, son yıllarda ani ve şiddetli yağışların artış gösterdiği Edirne'de bulunan Geçici Dünya Miras listesinde yer alan II. Bayezid Külliyesi yapılarına uygulanarak külliye yapılarının sel riski analiz edilmiş ve çalışma alanının sel riski haritası oluşturulmuştur.

Anahtar sözcükler: Edirne II. Bayezid Külliyesi; iklim değişikliği; mimari miras sel riski analizi; mimari mirasta sel hasarları.

\section{Giriş}

Bilim insanları, son yüzyılda yerkürenin sıcaklığında, Sanayi Dönemi öncesine göre yaklaşık $1^{\circ} \mathrm{C}$ artış saptamışlardır (Intergovernmental Panel on Climate Change-IPCC, 2018). İnsan kaynaklı olduğu kesinleşen bu $1^{\circ} C^{\prime}$ lik artş; dünya ikliminin değişmesine ve buna bağlı olarak atmosferik olayların artmasına neden olmuştur. IPCC'nin raporuna göre, gerekli önlemler alınmazsa, 2100 yılına kadar küresel ısınmadaki artışın $2^{\circ} \mathrm{C}^{\prime}$ nin üzerinde olacağı öngörülmektedir. Yerkürenin $1^{\circ} \mathrm{C}^{\prime}$ lik ısınması, konuya uzak olanlar için çok yüksek bir artı̧̧ olarak algılanmamaktadır (Farmer ve Cook, 2013). Ancak $1^{\circ} \mathrm{C}^{\prime}$ lik artışın neden olduğu düşünülen aşırı hava olaylarındaki artış, yağıs rejimlerinde düzensizlikler, aşırı sıcak hava dalgaları ve tüm bunların neden olduğu afetler gibi mevcut etkiler (IPCC, 2018, s. 69) dikkate alındığında $2^{\circ} \mathrm{C}$ veya üzerinde bir ısınmanın olumsuz etkileri daha öngörülebilir olmaktadır.

iklim değişikliği "küresel ısınmanın" bir sonucu olarak görüldüğünden "kuraklık", "çölleşme" veya "aşırı sıcaklık" etkisi daha olası kabul edilmekte ve iklim değişikliği ile sel arasında doğrudan bir etkinin varlığı anlaşılmamaktadır. Su döngüsündeki en önemli unsur buharlaşmadır; ısınarak genleşen hava daha çok su buharı taşımakta ve ani ısı değişimleri sonucunda kapasitesinin üzerindeki suyu ani ve şiddetli yağış olarak bırakmaktadır (Kurnaz, 2019). Böyle durumlarda seylaplar (ani sel) birkaç dakika içinde bile suların kabarmasına neden olmaktadır. Bu yağışlarda bazen toplamda bir mevsim boyunca olabilecek yağış miktarı sadece dakikalar içerisinde düşmektedir (Spennemann, 1999). Atmosferde ne kadar fazla enerji varsa hava olayları o oranda şiddetlenmektedir ve yapılan ölçümler atmosferde enerjinin arttğını göstermektedir; artan enerji daha fazla buharlaşmaya bu da aşırı hava olaylarında artş̧a neden olmaktadır (Kurnaz, 2019). Son yıllarda meydan gelen seller, kısa süreler içerisinde özellikle kentlerde büyük yıkımlara neden olmaktadır (Arnbjerg-Nielsen ve ark. 2013; Pelling, 2011). İklim değişikliği etkisi ile bu tür sellerin sayısında ve şiddetinde artş̧ beklenmektedir (IPCC, 2018).

Uluslararası Afet Veri Tabanı (Emergency Events Database: EM-DAT) karşılaştırmalı doğal afet verileri incelendiğinde, Dünya'da iklim değişikliği nedeniyle "katastrofik" olarak adlandırılan büyük ölçekli doğal afetlerden hidrometeorolojik karakterli olanların sayısında 1980 yılından beri sürekli ve önemli artşlar olduğu görülmüştür (URL1). Elde edilen verilere göre Avrupa'da, 1980 yılından beri yaşanan afetlerin \%64'ünün doğrudan sel, firtına, kuraklık ve sıcak hava dalgaları gibi şiddetli hava ve iklim koşulları nedeniyle meydana geldiği belirtilmektedir (Çevre ve Şehircilik Bakanlığı, 2012). Avrupa Çevre Ajansı (European Environment Agency: EEA) tarafindan hazırlanan raporda, iklim değişikliği etkisiyle 2050 yılında Avrupa'da sel kayıplarının beş kat artacağı belirtilmiştir (EEA, 2020). EM-DAT verilerine göre ise 2008-2018 yılları arasında sel afeti sayısı 149 iken sadece 2019 yılında bu sayı 194 olmuştur (Şekil 1).

Türkiye'nin de içerisinde bulunduğu subtropikal Akdeniz iklim kuşağında, iklim değişikliğine bağlı olarak kuraklık, şiddetli yağış ve ani sel, deniz seviyesinin artması gibi üç büyük sorun artma eğilimindedir (Kadıoğlu, 2007). Türkiye için yapılan iklim değişikliği projeksiyonlarının sonuçlarına göre, yağışlarda düzensizlik ve yağış miktarlarında azalma, bununla birlikte özellikle yaz aylarında Türkiye'nin bat ve kuzey kıyı kesimlerinde aşırı yağışların oluşma riski vardır (Demircan ve ark., 2017; Çelik ve ark., 2017). Türkiye'de aşırı yağışların son yıllarda gözlemlendiği gibi gelecekte de sel ve artan sıcaklığın; firtına, dolu ve hortum gibi aşırı hava olaylarının sayısında ve şiddetinde artışa neden olabileceği öngörülmüştür (Demircan ve ark., 2017). Türkeş'e (2020) göre ise Türkiye gelecekte, sıcak hava dalgaları ve kuraklık- 


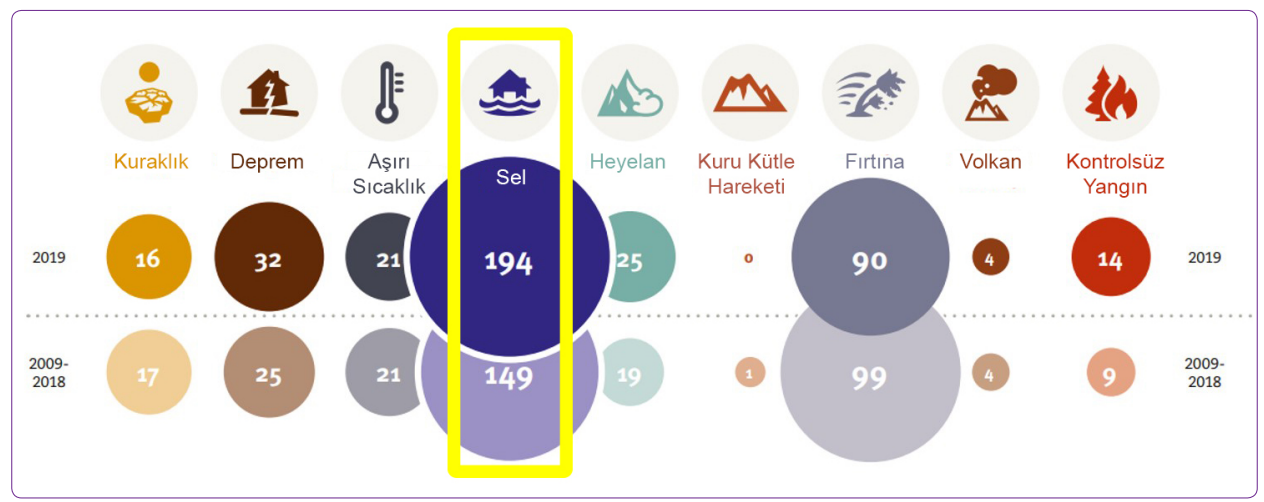

Şekil 1. EM-DAT 2009-2018 yılları arasındaki afet sayılarının 2019 yılı ile karşılaştııılması (URL1, 2020).

lardan, şiddetli ve aşırı yağış olayları ile gök gürültülü firttnalar ve hortum gibi hava olaylarından günümüze oranla daha fazla etkilenecektir.

Sel riskine yönelik çalışmalar havza bazlı yapılmakta olup yapı ölçeğinde riskler tespit edilmemektedir. Bu durum mimari mirasın selden hasar görebilirliğini ve potansiyel kayıpları artırmaktadır. Selin sayısında ve şiddetinde, mevcut ve gelecek için öngörülen artşlara rağmen konuyla ilgili koruma alanında henüz yeterli farkındalığın oluşmadığı ve çalışmaların özellikle ülkemizde çok yetersiz olduğu düşünülmektedir. Bu nedenle, bu çalışma kapsamında, sele karşı mimari mirası etkin olarak koruyabilmek için risk yönetiminde ilk adım olan potansiyel risklerin belirlenmesine yönelik, mimari mirasın her türüne uygulanabilir bir sel hasarı riski analiz modeli geliştirilmesi amaçlanmıştır. Çalışma, ulusal ve yerel afet yönetim planlamalarında yer almayan mimari mirasın sel risklerine dikkati çekerek koruma alanına olduğu kadar risk yönetim planlamalarında mimari mirasın yer almasına da katkı sağlayacaktır.

\section{Sel ve Kültürel Miras: Arka Plan}

İklim değişikliği, ani ve şiddetli yağışlarda artş̧a; bu yağışlar ise "şehir selleri" denilen ve kısa sürede afete dönüşen sel olaylarına neden olmaktadır (UNESCO, 2010). Dünya nüfusunun yaklaşık yarısı şu anda kentsel alanlarda yaşamaktadır ve bu oranın 2030 yılına kadar \%60'a ulaşacağı tahmin edilmektedir (Jha ve ark., 2012). Bu durum, kentleri gelecekte iklim değişikliğinin olumsuz etkilerine karşı daha riskli hale getirmektedir. İlim değişikliği etkilerinin ve kentleşmenin artacağı öngörüsüne dayanarak şehir sellerinin sayısında ve şiddetinde artış beklenmektedir (Drdacky ve ark., 2007; Vojinovic ve ark., 2016). Kentler açısından yıkıcı etkilere neden olan sel afeti, mimari mirasın tamamen kaybedilmesi dâhil olmak üzere geri dönüşsüz büyük hasarlara neden olmaktadır (Stovel, 1998; UNESCO, 2007; Dassanayake ve ark., 2012; Chelariu ve ark., 2016).

Selin kültürel miras üzerindeki yıkıcı etkileri 4 Kasım 1966 tarihinde Floransa'da meydana gelen seldeki geri dönüşsüz kayıplardan sonra daha iyi anlaşılmıştır (URL2). Kültürel mirasa ve ekonomik faaliyetlere verdiği zarar açısından kent tarihindeki en yıkıcı sel olarak kayıtlara geçen Floransa Seli (Galloway ve ark., 2017) kültürel mirasın sellere karşı savunmasızığını göstermekle kalmamış, önleyici korumanın önemini ve koruma uzmanlarının sel hasarları konusundaki bilgi eksikliklerini de ortaya çıkarmıştı (Brommelle, 1970; Lanza, 2003; Drdacky ve ark., 2007). Yaklaşık 250 tarihi yapının büyük oranda hasar gördüğü bir başka sel olayı, 1994 yılında Georgia Eyaletinde meydana gelmiştir. Tarihi Koruma Dairesi tarafindan yürütülen, sel esnası ve sonrası koruma ve restorasyon çalışmalarının yayınlanması ile selin mimari mirasa verdiği hasarın daha iyi anlaşılması sağlanmıştı (Historic Preservation Division, 1997). Bu sel afetinde de Floransa Selinde olduğu gibi kültürel mirasın sel riski ve sel hasarının restorasyonu konusunda uzman bilgisinin eksik olduğu anlaşılmıştr.

2002 yılında yaşanan Merkez Avrupa Selleri, Çek Cumhuriyeti, Avusturya, Almanya, Slovakya, Polonya Hollanda, Romanya ve Hırvatistan'da etkili olmuştur (Risk Management Solutions-RMS, 2002). Merkez Avrupa Sellerinden en çok etkilenen şehirlerden biri olan Prag'da (Nedvedova ve Pergl, 2013) hidrologların normal seviyenin 7 metre üzerinde öngördüğü, su seviyesinin gerçekte 8.5-9 metreyi bulacağı bilgisi, müzelere çok geç bildirilmiş ve pek çok müze tahliye sorunları ile karşı karşıya kalmıştır (Jirasek, 2003). Sular pik seviyeye ulaştğında en kötü senaryodan bile 1 metre daha fazla yükselmiştir ve kentte aralarında Dünya Miras Varlıklarının da olduğu pek çok kültürel miras hasar görmüştür (Jirasek, 2003; Mikule, 2004). Avrupa'da meydana gelen bu sellerde de risk altndaki kültürel mirasın durumu ve koşulları hakkındaki bilgilerin çok yetersiz olduğu ortaya çıkmıştır (Drdacky ve ark., 2007).

Yaşanan sel tecrübeleri kültürel miras varlıklarındaki kaybın, insan davranışıyla ilgili birçok hatadan kaçınılarak çok daha düşük olabileceğini göstermiştir (Drdacky ve ark., 2007; Jha ve ark., 2012). Buna bağlı olarak Avrupa ülkelerinde tarihi yapı kullanıcıları için tavsiye niteliğinde el ki- 
tapçıkları oluşturulmaya başlanmıştır. Örneğin, İngiltere'de English Heritage için Fidler ve arkadaşları (2004), tarihi yapıların sel risklerine hazırlıklı olması, tarihi yapıda sel hasarını azaltmaya yönelik yapısal ve yapısal olmayan önlemler ve sele maruz kalmış yapıların kurutulma ve iyileştirme sürecini içeren teknik tavsiye niteliğinde bir çalışma hazırlamışlardır. Historic England bünyesinde Pickles (2015) de tarihi yapılar için alınabilecek sel önlemlerini ve sel sonrası uygun müdahale yöntemlerini de içeren benzer bir çalışma yapmıştır. Ayrıca, Avrupa ülkelerinin çoğunda, özellikle sel afetinde acil durumlar için internet destekli büyük bilgi ve danışma sistemleri geliştirilmiştir (Drdacky ve ark., 2007).

Avrupa Birliği fonuyla 2007-2010 yılları arasında yürütülmüş konuyla ilgili en kapsamlı araştırma projesi "Cultural Heritage Protection Against Flood (CHEF)" projesidir (URL5). Proje kapsamında sel hasarı; binalarda ve temellerde; kentlerde ve miras alanlarında ve taşınabilir kültürel miras varlıklarında olmak üzere ayrı başıklar altında incelenmiştir (Drdacky ve ark., 2010a). Sel önlemlerinin; öncesi, esnası ve sonrası için oluşturulduğu projede; tarihi konutların, tarihi kentlerin, tarihi park ve bahçelerin, taş köprülerin, arşiv ve kütüphanelerin, müze objelerinin ve miras alanlarının sel hasarları, nedenleriyle birlikte araştırılmış ve proje raporunda çıkarılan derslerle birlikte verilmiştir.

"Mimari Koruma Eğitimi Konferansı" olarak 1959 yılında başlayan COTAC (Council on Training in Architectural Conservation) iklim değişikliğine de vurgu yaptığı 2014 yılındaki konferansın konusunu "Yapılı Çevrede Yangın ve Sel: Tehdidi Uzakta Tutmak" olarak belirlemiştir (URL3). Konferans sonuç raporunun sele ayrılan ikinci bölümünde "kültürel miras ve sel afeti" üzerine yapılan çalışmalar; kültürel mirası etkilemiş olan geçmiş sel afeti örnekleri; sele bağlı olarak yapıda oluşan hasarlar ve sel hasarını azaltmaya yönelik önlemler yer almaktadır (URL3).

Selin kültürel miras üzerindeki etkileri konusunda ulaşılan en eski kaynaklardan biri Stovel'ın (1998) kültürel mirasın afet risklerine hazırlıklı hale getirilmesi konusundaki kitabıdır. Bir bölümü sel afetine ayrılan kitapta, sel hasarları; yapıda ve bileşenlerinde; tarihi çevrede; kültürel peyzajda ve arkeolojik alanlarda olmak üzere üç ayrı başlık altında incelenmiştir. 2000'li yıllardan itibaren kültürel miras ve sel üzerine yapılan çalışmalarda artş dikkati çekmektedir. Lollino ve Audisio (2006) bir miras varlığının risklerinin hesaplanmasında bulunduğu bölgenin riskleri kadar miras varlığının kendi hasar görebilirliğinin de önemli olduğunu belirttikleri çalışmalarında İtalya'daki Dünya Miras Varlıkları için en yüksek risk olarak heyelan ve sel hasarlarını belirtmişlerdir. Dünya Miras Varlıklarının sel riskine yönelik bir başka çalışma Vojinovic ve arkadaşları (2016) tarafindan Ayutthaya için yapılmıştr. Çalışmada giderek artan kentleşmeye bağlı olarak geçirimsiz zeminlerin arttı̆ı ve şiddetli yağışlarda zeminde su emilimi olmaması nedeniyle kısa sürede yağışın sele dönüştüğü vurgulanmakta ve iklim değişikliği etkisi ile beraber aşırı yağışların sellerde artı̧a neden olacağı belirtilmektedir (Vojinovic ve ark., 2016).

Son yıllarda yapılan çalışmalarda kültürel mirasın sel risklerine yönelik "önleyici koruma” kavramına vurgu yapılmakta ve doğal afetler önlenemese bile riskler hesaplanarak gerekli önlemler alındığı takdirde potansiyel kayıpların en aza indirilebileceği görüşü öne çıkmaktadır. Taiwan'daki kültürel miras varlıklarının sel riskinin ölçülmesine yönelik yaptı̆̆ çalışmada Wang (2014), iklim değişikliğinin aşırı hava olaylarını artıran etkisine vurgu yapmış ve önleyici korumanın öneminden bahsetmiştir.

Önleyici korumanın önemine vurgu yapan bir başka çaış̧mada, Ortiz ve arkadaşları (2016) İspanya'nın Sevilla şehrinin tarihi kent merkezinin sel hasarına yönelik risk haritalarını oluşturarak Sevilla'da 13-18. yüzyıllar arasında inşa edilmiş kiliselerin olası hasarlarını tespit etmek amacıyla bir yöntem geliştirmişlerdir. Benzer şekilde Li ve arkadaşları (2017) da kültürel mirasın doğa ve insan kaynaklı pek çok risk taşıdığını, sellerin bunlar arasında en yaygın ve yıkıcı etkiye sahip afet olduğunu belirterek önleyici korumanın önemine dikkati çekmişlerdir.

"Floods: Volume 1-Risk Knowledge" adlı kitabın dördüncü bölümü selin kültürel mirasa etkilerine ayrılmıştı (Deschaux, 2017). illgili bölümde kültürel mirasa zarar veren büyük tarihi seller ve kültürel mirasta selin oluşturduğu hasarlar farklı başlıklar altında incelenmiştir. Bedeaux ve arkadaşları (2018) ise sellerin kültürel miras üzerindeki olumsuz etkilerinin iklim değişikliği bağlamındaki önemine vurgu yapmış ve kültürel mirasın sel riski yönetimi ve risk altındaki alanların tespiti konularını irdelemişlerdir.

iklim değişikliğinin de etkisiyle dünyanın hemen her yerinde yaşanan aşırı yağışlara bağlı şehir sellerindeki artışlar, kültürel mirasın hasar görebilirliğini artırmaktadır. Güncel literatür tarandığında, yurt dışında kültürel mirasın selden korunmasına yönelik endişe ve farkındalığın özellikle 2000 'li yıllarda arttı̆ı anlaşılmaktadır. Yurt dışı çalışmaların aksine Türkiye'de konuya ilginin yeterli seviyede olmaması ve bu alanda literatür eksikliği dikkati çekmektedir. Ülkemizde mimari mirasın sel riski ve sel hasarı üzerine yeterli seviyede çalışma yapılmamış olması, bu bölüm başında verilen büyük sel örneklerinde olduğu gibi miras varlıklarının hasar riskini artırmaktadır. Tarihi kentler ve miras varlıkları için sel riskine yönelik hassas ve bilinçli yaklaşımlar geliştirilmelidir çünkü kültürel mirasta selin oluşturduğu hasardan daha fazlası, sele karşı alınan önlemlerle (Nedvedova, 2013; Nedvedova ve Pergl, 2013 ) veya sel sonrası yapılan yanlış müdahalelerle oluşmaktadır (National Trust, 2005).

\section{Mimari Miras Sel Riski Analiz Modeli (MiSRAM)}

Sel riski analizleri genellikle havza bazlı yapılmaktadır. Bir bölgenin sel riskinin hesaplanabilmesi için topoğrafya, sel 
tekerrür periyotları, geçmiş sellerin yayılım (etki) alanları, bölgenin zemin özellikleri, arazi kullanımındaki değişiklikler vb. veriler gereklidir. Havza bazlı sel riski analizlerinde coğrafi bilgi sistemlerinden faydalanılarak sel riskli alanlar tespit edilmektedir. Yerleşim olmayan bölgelerde bile, sel riski analizi pek çok değişkenin bir arada işlenmesi ile elde edilen zorlu bir uygulamadır (Gandini ve ark., 2018). Havza bazlı analizler büyük ölçeklerde gerçekleştirilen makro ölçek çalışmalar iken kentlerin sel riski analizinde veri ölçeğinin küçülmesi ve çalışmanın mikro ölçekte yapılması gerekmektedir. Kentleşme sürecinde topoğrafya büyük oranda değişmiş; zemin, geçirimsiz malzemelerle kaplanmıştir. Planlı ya da plansız altyapılar oluşturulmuştur. İnşa edilen binalara bir veya birden fazla bodrum kat yapılmıştır. Sonuç olarak kentlerde sel riski için keskin sınırlar çizilerek belli bir bölgenin havza bazlı verilere dayanarak, sel riski yüksek olarak belirlenmesi, o bölgedeki her yapının eşit sel riskine sahip olduğunu ifade etmemektedir. Her yapının kendi özellikleri ve mevcut durumu üzerinden risklerinin hesaplanması gerekmektedir. Kaybı, maliyet hesabı ile belirlenemeyecek olan ve sahip olduğu miras değerleri nedeniyle daha farklı değerlendirilmesi gereken mimari mirasın sel hasarı riskinin analizi de yapı ölçeğinde yapılmalıdır. Sel olaylarında mimari mirasın sel riski ve hasarı değerlendirilirken, koruma kararlarının göz önünde bulundurulması ve konuya uzman bakışı gerektiği için mimari miras ayrı bir vaka olarak ele alınmalıdır (Jha ve ark., 2012). Bu doğrultuda çalışma kapsamında mimari mirasın sel hasarı riskinin de mikro ölçek saha çalışması ile tespit edilmesine yönelik bir model geliştirilmiştir.

Model, dört adımda oluşturulmuş ve uygulanmıştır (Şekil 2). Birinci adımda, mimari mirasta sel kaynaklı hasarların neler olduğu araştııımış; hasarı artıran parametrelerin belirlenmesi için yerinde tespit, gözlem ve incelemeler yapılmış; tarihi sellere yönelik arşiv ve literatür taranmıştir. Elde edilen verilerden sel kaynaklı kuvvetler ve etkiler; bu kuvvet ve etkilerin mimari mirasta oluşturduğu hasar türleri, hasarın oluştuğu bölgeler ve olası hasar riskleri belirlenmiş-

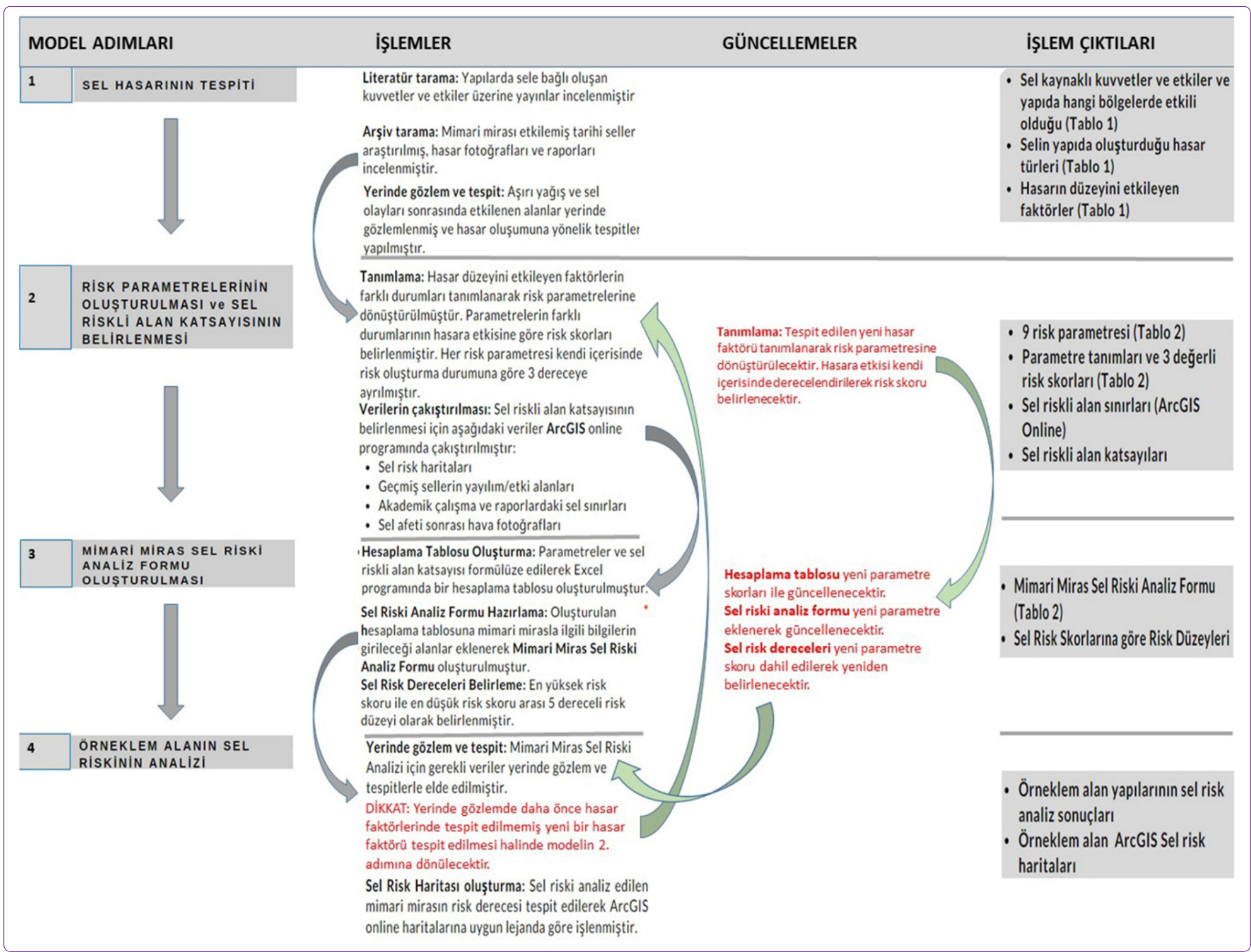

Şekil 2. MiSRAM geliştirme ve uygulama akış diyagramı (Gökmen Erdoğan ve Ünal, 2021). 
tir. Daha sonra hasar risklerinin düzeyini etkileyen faktörler tespit edilmiştir. İkinci adımda, hasar düzeyini etkileyen faktörler risk parametreleri haline getirilerek hasar düzeyini ne şekilde etkiledikleri tanımlanmış ve her risk parametresi "yüksek, orta ve düşük risk oluşturma" düzeyine göre üç değerli risk skorları oluşturulmuştur. Bununla birlikte mimari mirasın bulunduğu bölgenin sel riskli alan katsayısının belirlenmesi için, alana yönelik risk haritaları elde edilmiş ve geçmiş sellerin etki (yayılım) alanları ile çakıştırılmıştır. Sel riskli alan katsayısı yüksek, orta ve düşük olmak üzere üç değerli olarak belirlenmiştir. Üçüncü adımda, belirlenen risk parametreleri ile sel riskli alan katsayısı, hesaplamada kullanılmak üzere Excel programında bir hesaplama tablosuna dönüştürülmüştür. Oluşturulan sel riski analiz tablosuna mimari mirasa ait bilgilerin yer alacağı yapı künyesi kısmı eklenerek "Mimari Miras Sel Riski Analiz Formu" oluşturulmuştur. Dördüncü adımda, II. Bayezid Külliyesi yapılarının sel riskinin analizi için yerinde tespit çalışması yapılarak veriler her yapı için oluşturulan Mimari Miras Sel Riski Analiz Formlarına işlenmiştir. Sel riski analiz edilen mimari miras yapıları risk düzeylerine göre ArcGIS Online uygulamasında belirlenen risk lejantlarına göre işlenerek örneklem alanın sel riski haritası oluşturulmuştur. Geliştirilen modelin dördüncü adımında yerinde gözlem ve tespit işlemi esnasında, sel risklerini artiran mevcut hasar faktörlerinden farklı bir hasar faktörü ile karşılaşılması durumunda modelin ikinci adımına geri dönülecektir. Ortaya çıkan yeni hasar faktörünün tanımlaması yapılarak risk parametresine dönüştürülme ve oluşturduğu hasar düzeyine göre kendi içerisinde derecelendirilerek risk skorlarının belirlenme işlemleri bu adımda yapıldıktan sonra bir sonraki adıma geçilecektir. Üçüncü adımda yeni parametre, hesaplama tablosuna ve sel riski analiz formuna dâhil edilerek dokümanlar güncellenecek ve yeni parametrenin risk skorları da dâhil edilerek sel risk derece aralıkları yeniden hesaplandıktan sonra tekrar dördüncü adıma geçilecektir (Şekil 2).

\section{Mimari Mirasta Sel Hasarı}

Sel olayının mimari miras üzerinde doğrudan veya dolaylı pek çok olumsuz etkisi vardır. Seller, mimari mirasta gözle görülen dış etkiler kadar dışardan fark edilmeyen iç etkiler de oluşturmaktadır (Şekil 3, 4). Bu çalışma kapsamında, kültürel mirasta sel hasarlarının incelendiği araştrmalardan (National Trust, 2005; English Heritage, 2010; Drdacky ve ark., 2010b; Daungthima ve Kazunorib, 2013; Snow, 2014; Deschaux, 2017), geçmiş sel afetlerinden sonra hazırlanmış rapor ve videolardan (Historic Preservation Division, 1997; Jirasek, 2003; Mikule, 2004; Pickles, 2015; URL4; URL5; URL6), sel olaylarına yönelik gazete arşivlerinden (URL7) ve sel sonrası yerinde gözlemlerden elde edilen verilerle fiziksel, kimyasal ve biyolojik hasarlar ve bu hasarların oluşumuna neden olan sel kaynaklı kuvvet ve etkiler tespit edilmiştir (National Trust, 2005; Drdacky ve ark., 2010b; Snow, 2014). Selin yaşandığı bölgenin özelliklerine göre farklılık gösterebilen bu kuvvet ve etkiler aşağıda maddeler halinde verilmiştir:

1. Yatay yönlü hidrostatik basınç,

2. Yüksek hızlı dinamik akış etkisi,

3. Yukarı yönlü hidrostatik basınç,

4. Suyun aşırı kaldırma kuvveti,

5. Sürüklenen/yüzen objelerin dinamik etkisi,

6. Bariyer/engel oluşması,

7. Buz kütlesi taşınması,

8. Miras varlıklarının kirlenmesi,

9. Malzemelere kimyasal ve biyolojik kirleticilerin bulaşması,

10. Zemin suyu etkileri,

11. Dâhili erozyon,

12. Toprak özelliklerinin mekanik değişimleri,

13. Temel malzemelerinde bozulma,

14. Malzemelerin su emmesi,

15. Sel sonrası etkiler.

Selin verdiği hasar kadar selden sonra yapılan yanlış müdahaleler de ciddi hasarlara neden olmaktadır. Örneğin, bodrumdaki suların tahliye edilme işlemi, sel nedeniyle yükselmiş olan zemin suyu seviyesi normale dönmeden

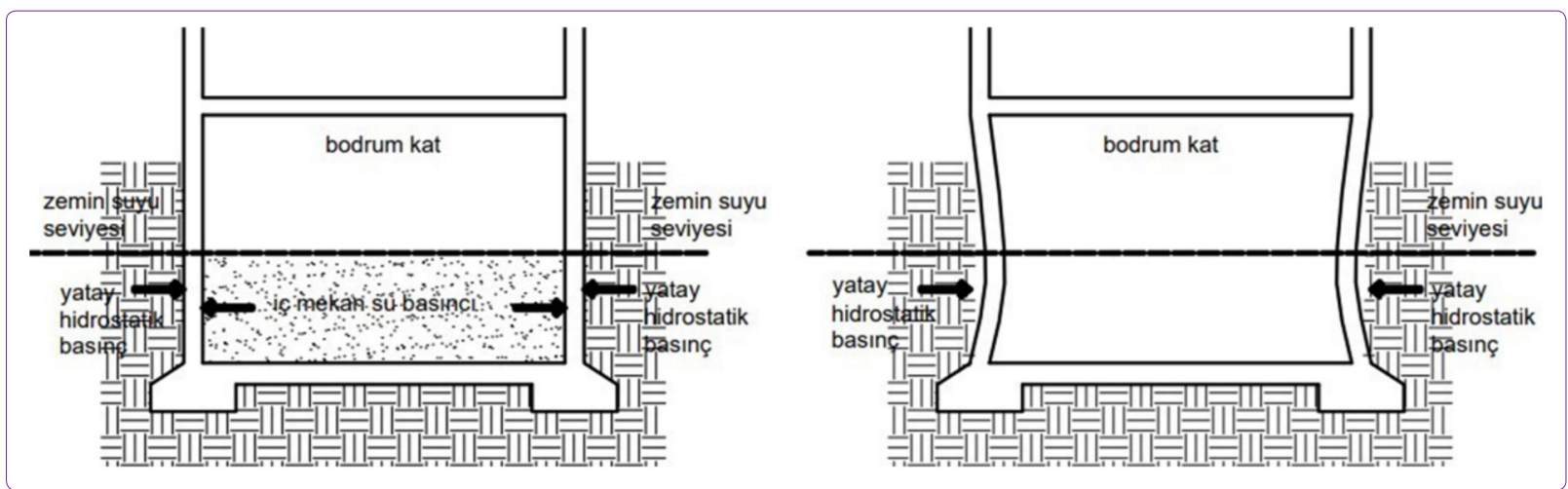

Şekil 3. Bodrum kattaki sel suları tahliye edilmeden önce (sol) ve edildikten sonraki (sağ) kuvvetler (National Trust, 2005). 
yapıldığında dışarıdan temel/bodrum duvarına etki eden yatay hidrostatik basınç kuvvetlerini dengede tutacak bir iç kuvvet kalmadığından Şekil 3'tekine benzer hasarlar ortaya çıkmaktadır (National Trust, 2005).

Şekil 3'te görüldüğü gibi büyük hasarlar kadar yapıda daha basit sel hasarları da oluşmaktadır. Örneğin, duvar içerisine hapsolmuş su, çözünebilir tuzları çözmekte ve su duvar yüzeyine doğru hareket ederken beraberinde bu tuz ve çökeltileri de taşımaktadır. "Çiçeklenme" adı verilen bu birikintiler genellikle zararsızdır ve kolay temizlenebilmektedir (National Trust, 2005) (Şekil 4a). Ancak özgün bezemeler için uygun yöntemlerle temizleme yapılmadığında bu basit oluşum ciddi bir tehdide dönüşmektedir. Mevsime bağı ı olarak sel esnasında duvar içerisinde hapsolmuş su donmakta ve genleşmekte, bunun sonucunda çatlaklara ve malzeme kayıplarına neden olmaktadır (Şekil 4b). Yüzey su geçirimsiz malzeme ile kaplı ise su yüzeye ulaşamamakta ve buharlaştkça çözünmüş tuzlar yeniden kristalize olmakta, içeride genleşerek duvar yüzeyinde hasara neden olmaktadır (Şekil 4c).

Sel hasarları çok çeşitlidir ancak bu çalışma kapsamında hepsinin örneklendirilmesi mümkün olmadığından mimari mirasta sel nedeniyle oluşan fiziksel, kimyasal ve biyolojik hasar türleri, oluşumuna neden olan kuvvet ve etkilere göre sınıflandırılmıştır. Bu etki ve kuvvetlerin yapılarda oluşturdukları hasar riskleri incelenmiş ve hasar riskini artran faktörler tespit edilerek "Mimari Mirasta Sel Etkileri ve Hasar Riskleri" olarak bir araya getirilmiş ve "sel kaynakI kuvvetler/etkiler; hasar riskleri; hasar düzeyini etkileyen faktörler" ayrı sütunlarda Tablo 1'de gösterilmiştir.

Tablo 1'de verilen hasar riskleri incelendiğinde; her yapının eşdeğer sel hasarı riski taşımadığı ve yapının mevcut özelliklerinin ve durumunun hasarın boyutunu etkilediği anlaşılmaktadır. Buna göre hasarın boyutlarını etkileyen dokuz faktör; bölgenin altyapısı, yapının sağlamlığı, yapı zemin kotunun yol (dış) kotu ile ilişkisi, yapının konumu, yapım sistemi ve malzemesi, yapının bakım sorumluluğunun kime ait olduğu, yapının bakımlarının yapılma sıklığı, yapının kullanım durumu ve yapının işlevi olarak ortaya çıkmaktadır. Bu faktörler MiSRAM'da kullanılmak üzere risk parametrelerine $(p)$ dönüştürülmüştür.

\section{Risk Parametreleri ve Riskli Alan Katsayısı}

Mimari mirasın sel riskini analiz etmek için önerilen modelde, sel risk düzeyinin belirlenmesi için risk parametrelerinden elde edilecek risk skoruna ve sel riskli alan katsayısına intiyaç vardır. Bu bölümde risk parametreleri tanımlanarak sel hasarına etkileri derecelendirilmiş; risk skorları belirlenmiştir ve örneklem alan için riskli alan katsayılarını tespit etmeye yönelik yöntem belirlenmiştir.

\section{Risk Parametreleri}

MiSRAM'da kullanılmak üzere Tablo 1'deki bulgulardan elde edilen parametrelerin (p) risk düzeyine etkileri aşağıda tanımlanmaktadır:

p1 bölgenin altyapı durumu: Hızlı kentleşme sonucunda pek çok kentin halihazırda önemli sorunlarından olan altyapı yetersizliği sellerin oluşumunda ve hasarın boyutunda büyük etkiye sahiptir. İklim değişikliği etkisiyle ani ve şiddetli yağışların artacağı düşünüldüğünde yapının bulunduğu bölgenin altyapı durumu, gelecekte günümüzde olduğundan daha önemli bir parametre olacakttr. Çünkü iklim değişikliği etkisiyle oluşan ani ve şiddetli yağışlarda bazen bir mevsimin toplam yağışı, dakikalar içerisinde meydana gelmekte ve yetersiz kalan altyapılar bu yağışları karşılayamamaktadır. Mimari mirasın bulunduğu bölgedeki altyapı durumu, bölgede sel oluşumu ve yapıda oluşacak hasarın boyutu açısından önemli bir parametredir (Lanza, 2003; Vojinovic ve ark., 2016).

p2 yapının sağlamlı̆̆: Yapının, yapı elemanlarının ve yapı malzemeleri ile beraber günümüzdeki mevcut durumunu başka bir deyişle bütünlüğünü, hasarsızlığını ifade eden sağlamlık parametresi tüm afet türleri için hasar riskini etkileyen önemli bir parametredir. Yapının iyi korunmuş ve sağlam olması sel suyunun şiddetine ve selin taşıdığı yüklere karşı direncini artırırken; yapı statiğindeki noksanlıklar yapının bu yüklere dayanımını azaltacak ve hasar riskini artiracaktır.

p3 yol kotu ile yapı en alt zemin kotu ilişkisi: Zemin suyu etkilerine, sel suyuna ve taşıdıklarına maruz kalma derecesini belirleyen parametrelerden biri de yapının en alt kat zemin döşemesi kotunun, yol kotu ile ilişkisidir. Bodrum kat

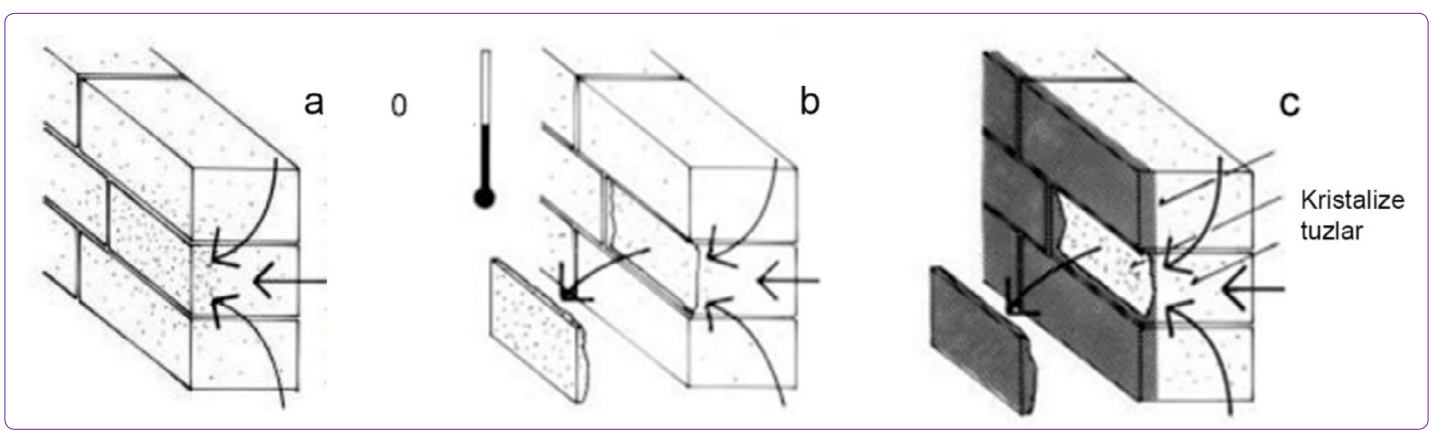

Şekil 4. Taş/tuğla duvarda hapsolmuş sel suyu etkileri (National Trust, 2005). 
Tablo 1. Mimari mirasta sel etkileri ve hasar riskleri (Gökmen Erdoğan ve Ünal, 2021)

\section{Sel kaynaklı kuvvetler/etkiler \\ Hasar riskleri (olası hasar türleri ve hasarın meydana geldiği yerler)}

Yatay yönlü

hidrostatik basınç

Binanın tamamında ve/veya temellerde etkili olabilir.

Kapı, pencere vb. doğramalar ve camlar hasar görebilir.
Tarihi bahçe duvarları, kısmen ayakta kalmış miras yapılarının tekil duvarları hasar görebilir.

Toprak basıncının artması ile bodrum kat ve/veya istinat duvarları etkilenebilir.

Toprak üstü tarihi kalıntılar ve arkeolojik alanlara zarar verebilir.

Yükselen ve yüzen dengesiz objelerin yer değiştirmesine ve devrilmesine neden olabilir. Jeoteknik koşulların etkilenerek oyuk ve çökmelerin oluşması ve bunlara bağlı daha büyük hasarların oluşmasına neden olabilir.
Hasar düzeyini etkileyen faktörler

Sağlamlık durumu

Konum

Bakım sorumluluğu

Yapı zemin-yol kotu

ilişkisi/bodrum kat

varlığı

Kullanım durumu

İşlev

Bakım durumu

Sağlamlık durumu

Konum

Bakım sorumluluğu

Yapı zemin-yol kotu

ilişkisi/bodrum kat

varlığı

Kullanım durumu

İşlev

Bakım durumu

Miras yapısının işlevi Bölgede altyapı

durumu

Konum

Bölgede altyapı

durumu

kaldırma kuvveti

Zemin strüktürlerinde hasar/yer değiştirmeler olabilir.

Tüm bina kütlesi zeminden kalkabilir.

Temellerde çatlaklar oluşabilir.

Temel altında boşluklar oluşabilir.

İç erozyon olabilir.

Temel çökebilir.

Sürüklenen/yüzen objelerin dinamik etkisi

Bariyer/engel

oluşması

Buz kütlesi

taşınması
Araçlar, kent mobilyaları, kütükler, binalardan taşınan yapı elemanı ve mobilyalar vb. sıklıkla görülen sel suyu ile sürüklenerek yüzen objelerdir. Yüzen objenin boyutu ve suyun akış hızına göre akış hattı üzerinde çarpacağı yapılarda oluşturabilecekleri hasarlar ve bu hasarların belirsizliği riski

Buz kütlesi taşınması veya akış etkisi ile yüzen/sürüklenen objelerin bir yerlerde birikerek bariyerler/engeller oluşturması ve bu bariyer ve engellerin etkisiyle:

Su seviyesi yükselebilir.

Sel esnasında ve/veya sonrasında müdahale/kurtarma ekiplerinin ulaşımı aksayabilir. Köprü ayakları altındaki toprağın oyulma tehlikesi artabilir.

Set ve nehir bariyerlerinde hasar oluşabilir.
Miras varlıklarının

kirlenmesi/

malzemelere

kimyasal

ve biyolojik

kirleticilerin

bulaşması
Normal bir selde genellikle çamur ve moloz taşınırken (örn. Floransa 1966 Seli) selin nerede olduğuna bağlı olarak bazen farklı maddeler sel suyuna karışmaktadır. Geçmişte yaşanan sellerde kanalizasyon suları, petrol, yağ vb. maddelerin sel suyuna karıştığı örnekler yaşanmıştır.

Sel suyu muhteviyatına bağlı olarak miras yapısında kirlenme oluşabilir.

Demir ihtiva eden malzemeler ve/veya güçlendiriciler tehlikeli kloridlerin saldırısına uğrayabilir.

Etkin olmayan ajanlar yeniden büyüyebilir
Konum

Sağlamlık

Bakım durumu

Bakım sorumluluğu

Kullanım durumu 
Tablo 1. Mimari mirasta sel etkileri ve hasar riskleri (Gökmen Erdoğan ve Ünal, 2021) (devamı)

\begin{tabular}{|c|c|c|}
\hline $\begin{array}{l}\text { Sel kaynaklı } \\
\text { kuvvetler/etkiler }\end{array}$ & Hasar riskleri (olası hasar türleri ve hasarın meydana geldiği yerler) & $\begin{array}{l}\text { Hasar düzeyini } \\
\text { etkileyen faktörler }\end{array}$ \\
\hline Zemin suyu etkileri & $\begin{array}{l}\text { Zemin suyunun yükselmesiyle oluşan riskler: } \\
\text { Yapı altlarındaki toprak durumunda değişiklik, toprak sertliğinde azalma, toprak içinde } \\
\text { erozyon oluşabilir. } \\
\text { Yapının stabilizesinde tehditler oluşabilir. } \\
\text { Illk defa doygunluk durumunda toprak çökebilir. } \\
\text { Su emiliminden dolayı toprak şişebilir. } \\
\text { Strüktürlerde yukarı yönlü aşırı kuvvet oluşabilir. } \\
\text { Temel malzemelerinde bozulma meydana gelebilir. } \\
\text { Yerleşim zemini çökebilir (özellikle ilk kez sel yaşanan yerlerde) }\end{array}$ & $\begin{array}{l}\text { Konum } \\
\text { Sağlamlık } \\
\text { Altyapı durumu }\end{array}$ \\
\hline Dâhili erozyon & $\begin{array}{l}\text { Zemin daha gevşek ve çökmeye elverişli hale gelebilir. } \\
\text { Üst yapı oturması olabilir. } \\
\text { Üst yapının dengesinin bozulabilir. }\end{array}$ & $\begin{array}{l}\text { Konum } \\
\text { Zemin özellikleri } \\
\text { Sağlamlık }\end{array}$ \\
\hline $\begin{array}{l}\text { Toprak } \\
\text { Özelliklerinin } \\
\text { mekanik } \\
\text { değişimleri } \\
\text { Temel } \\
\text { malzemelerinde } \\
\text { bozulma }\end{array}$ & $\begin{array}{l}\text { Zemin suyu seviyesindeki dalgalanma toprağın etkili gerilmelerinde değişime neden } \\
\text { olur. } \\
\text { Toprağın mekanik özelliklerinden çoğunun etkili gerilmelere bağlı olmasından dolayı } \\
\text { toprağın kayma mukavemeti ve sertliğinde değişim oluşabilir. } \\
\text { Hafif strüktürlerde hasar oluşabilir. } \\
\text { Mantar ve bakteri deformasyonu meydana gelebilir. } \\
\text { Temel malzemesinin bozulmasına bağlı üst yapı yükleri çökebilir. }\end{array}$ & $\begin{array}{l}\text { Konum } \\
\text { Altyapı durumu } \\
\text { Zemin özellikleri } \\
\text { Yapım sistemi } \\
\text { /malzemesi } \\
\text { Bakım durumu } \\
\text { Bakım sorumluluğu }\end{array}$ \\
\hline $\begin{array}{l}\text { Malzemelerin su } \\
\text { emmesi }\end{array}$ & $\begin{array}{l}\text { Hacimsel değişiklik oluşmasına neden olabilir. } \\
\text { Kimyasal etkiler ortaya çıkabilir. } \\
\text { Dayanıklılık kaybı oluşabilir. } \\
\text { Su emmenin boyutuna bağlı olarak yapı göçebilir. } \\
\text { Ahşap yapı elemanlarında şişme ve genleşme; ahşap kirişlerde bükülme oluşabilir. } \\
\text { Duvarlarda çatlaklar, duvar yüzeylerinde pul pul dökülme meydana gelebilir. }\end{array}$ & $\begin{array}{l}\text { Yapım sistemi } \\
\text { /malzemesi } \\
\text { Konum } \\
\text { Zemin-yok kotu ilişkisi } \\
\text { Bakım durumu } \\
\text { Sağlamlık }\end{array}$ \\
\hline Sel sonrası etkiler & $\begin{array}{l}\text { Tavanlar çökebilir. } \\
\text { Moloz ve enkaz birikimi artabilir. } \\
\text { Bezemeler hasar görebilir/tamamen kaybedilebilir. } \\
\text { Malzeme mukavemetinde azalma meydana gelebilir. } \\
\text { Yanlış müdahaleler ve kurutma yöntemlerine bağlı hasarlar oluşabilir. } \\
\text { Biyolojik bozulmalar oluşabilir. } \\
\text { Kuruma süreci ve sonrasında hasar oluşması, kuruma } \\
\text { sürecinde dökülme ve ayrılmalar oluşabilir. }\end{array}$ & $\begin{array}{l}\text { Kullanım durumu } \\
\text { Bakım sorumluluğu } \\
\text { Altyapı durumu }\end{array}$ \\
\hline
\end{tabular}

varlığı ya da zemin katın döşeme seviyesinin yol kotunun altında kalması; yapının temel ve duvarlarının, zemin suyu, toprak özelliklerinde değişim ve selle taşınan çamur, moloz vb. nesneler kaynaklı ortaya çıkan etki ve kuvvetlere maruz kalma riskini artırmaktadır. Ayrıca yapı içerisinde biriken sel suyu ve selin taşıdığı nesnelerin tahliyesini zorlaştracaktır.

p4 konum: Sellerde hasarı artıran en önemli parametrelerden biri de yapının konumudur. Geçmiş seller ve literatür incelendiğinde sellerden konum olarak en fazla etkilenen alanlar; dere yatakları, nehir, gölet, göl vb. su kaynaklarının kenarları, yerleşimin en alt kotlarında kalan düzlük alanlardır. Özellikle ani ve şiddetli yağışlarda oluşan sel suları, yerleşimin üst kotlarından alt kotlara doğru hız- lanarak akmakta ve varsa taşan su kaynakları ile birleştiği bölgelerde en büyük hasarı oluşturmaktadır. Selin boyutuna göre bazen haftalarca sular çekilmediğinden bu bölgelerde bulunan mimari mirasın hasar riski yüksektir.

p5 yapım sistemi ve malzemesi: Yapım sisteminde kulIanılan malzemelerin suya olan hassasiyetine ve yapıda kullanım şekillerine (yığma, karkas vb.) göre hasar görme riskleri farklılaşmaktadır. Örneğin, ahşap gibi suyu bünyesine çabuk alan (Tablo 2) ve su ile temasında uygun kurutulma yapılmazsa zararlı organizmaların gelişimine bağı olarak bozulmaya uğrayan malzemeler (Eriç, 1994) ve bu malzemeleri içeren yapım sistemlerinin sel hasarı riski daha yüksektir. 
Tablo 2. Malzeme türlerine göre ağırlıkça su emme, basınçlı su geçirimlilik ve kapilarite katsayıları (Eriç, 1994)

\begin{tabular}{|c|c|c|c|c|}
\hline Malzeme & $\mathbf{S}_{\mathrm{a}} \%$ & $k_{1} \mathrm{~cm} / \mathrm{sn}$ & $k_{2} \mathrm{~cm}^{2} / \mathrm{sn}$ & $\Delta \mathbf{b} \%$ \\
\hline Taş & $0.3-5$ & $10^{-9}-10^{-12}$ & $10^{-6}-10^{-7}$ & $0.004-0.15$ \\
\hline Çimento harcı & $30-50$ & $10^{-9}$ & $10^{-6}$ & $0.02-0.04$ \\
\hline Beton & $1-8$ & $10^{-7}$ & $10^{-5}$ & $0.01-0.08$ \\
\hline Tuğla & 8-18 & $10^{-6}-10^{-8}$ & $10^{-2}-10^{-4}$ & 0.01 \\
\hline Ahşap & $15-100$ & - & - & $5-15$ \\
\hline Plastik & $0.01-2$ & - & - & $0.10-0.50$ \\
\hline
\end{tabular}

p6 bakım sorumluluğu: Mimari mirasın sel hasarı düzeyi, yapının sele hazırlıklı olmasında veya sel sonrası uygun müdahalelerin yapılmasında kimin sorumlu olduğuna göre değişmektedir. Yapının bakımından sorumlu kişi ya da kurumların olmadığı veya belirsiz/karmaşık olduğu durumlarda mimari miras için selden korumaya yönelik ya da sonrasında onarım için gerekli müdahalelerin yapılmaması nedeniyle hasarın boyutu artmaktadır.

p7 bakım durumu: Yapının bakımından sorumlu olan kişi/kurum kadar yapının bakımlarının ne sıklıkta ve düzeyde yapıldığı da sel hasarını etkileyen parametrelerden biridir. Yapının periyodik bakımları özellikle afetlere yönelik kontrol listeleri ile (drenaj ve kanalizasyon sistemlerinin kontrolü, çatı elemanları ve kapı, pencere gibi yapı elemanlarııın bakımı vb.) yapıldığında sel hasarı riski de düşecektir.

p8 kullanım durumu: Korumada önemli noktalardan biri de yapıların bakımlarının sürekliliği için kullanımda kalmalarıdır. Kullanılmayan yapılar atıl kalmakta ve zamanla eskimektedir. Uzun süre önce terk edilmiş ve atıl kalmış yapıların selden hasar görme riski en üst seviyededir. Yapı yasal kiracısı ya da mülk sahibi tarafindan kullanılıyorsa hasar görme riski azalmaktadır.

p9 işlev: Yapının mevcut işlevi, mimari mirasın sel hasarı riskini farklı şekillerde etkileyen bir parametredir. Bu parametrede risk skoru belirlenirken çok keskin bir ayrıma gitmektense yerinde tespite göre karar verilmesi uygun görülmektedir. Ancak yerinde tespitte ölçüt oluşturması açısından risk dereceleri için tanımlar yapılmış ve işlev örnekleri verilmiştir. Örneğin, doğrudan suyla teması olan köprülerin gözleri sel suyu ile taşınan nesneler veya kış aylarında buz kütleleri ile tikanmakta ve yatay basınç kuvvetleri artmaktadır (Drdacky ve Slizkova, 2007). Bu nedenle köprü, su değirmeni vb. gibi hâlihazırda doğrudan suyla teması olan yapılar yüksek riskli tanımlanmıştır. Bununla birlikte müze, arşiv, kütüphane, sergi gibi içerisinde çok fazla hareketli ve kıymetli obje barındıran miras yapıları da yüksek riskli olarak tanımlanmıştr. İçeride bulunan çok sayıda ve hareketli obje sel esnasında suyun yukarı kaldırma kuvveti ile taşınarak geçişlerde engel ve barikatlar oluşturmakta; sel sonrasında ise ıslanmış ve kirlenmiş çok fazla obje- nin tahliye süreci uzun olacağından kısa sürede iç mekânda nem oranı artmakta ve zararlı organizmaların oluşumu başlamaktadır. Arkeolojik alan, mezarlık, hazire, şehitlik vb. işlevlere sahip miras varlıklarının, her türlü hava koşuluna açık olmakla birlikte genellikle suyun emilebileceği toprak zemin varlığı ve açık havada sular çekildikten sonra kuruma sürecinde hava ile temasının olması nedeniyle hasar risk düzeyi orta olarak tanımlanmıştır.

\section{Sel Riskli Alan Katsayısı}

Sel haritaları oluşturulmasında karşılaşılan en yaygın sorunlar; veri, uygun modelleme yazılımı ve kalifiye personel eksiklikleridir. Verilerin mevcut olmadığı durumlarda, tehlike haritalarının oluşturulması ve sayısallaştırıması için tarihi sel kayıtlarından (eski gazeteler ve/veya tarihi binalar üzerine işaretlenmiş sel derinlik izleri, önceki sellerden fotoğraflar) faydalanılabilir (Jha ve ark. 2012). Bu çalışma kapsamında örneklem alan için coğrafi bilgi sistemi uygulaması ile oluşturulmuş sel riskli alan sınırları (URL8), geçmiş sel yayılım alanları ile Autocad 2D programında çakıştırılarak karşılaştırılmıştır. Çalışma alanı sel risk haritasında işaretlenmiş ve yüksek sel riskli alan katsayısına sahip olduğu tespit edilmiştir. MiSRAM'da kullanılmak üzere sel riskli alan katsayısı için yüksek, orta ve düşük olmak üzere üç risk derecesi belirlenmiştir.

\section{Mimari Miras Sel Riski Analiz Formu}

Modelin geliştirilmesinde son aşamada, tanımlamaları yapılan ve dereceleri belirlenen risk parametreleri $(p)$ ile sel riskli alan katsayısı Excel programında bir araya getirilerek bir risk hesaplama tablosuna dönüştürülmüştür. Bu tabloya mimari mirasın; konumu, mevcut durumu, sel riski analiz sonucu ve risk grubunun yazılacağı yapı künyesi alanı eklenerek "Mimari Miras Sel Riski Analiz Formu” oluşturulmuştur (Tablo 3). Mimari mirasın sel risk düzeyini belirlemede kullanılacak sayısal değer olan "Sel Risk Skoru" (RS) hesaplaması için "Risk Parametreleri Toplam Skoru" $(\Sigma p)$ "Sel Riskli Alan Katsayısı" (RK) ile çarpılmıştır.

Risk parametreleri skoru ile sel riskli alan katsayısı çarpımından elde edilen en yüksek sel risk skoru 145 iken; en düşük sel risk skoru 9'dur. En yüksek ve en düşük sel risk 
Tablo 3. Mimari miras sel riski analiz formu (Gökmen Erdoğan ve Ünal, 2021)

\begin{tabular}{|c|c|c|c|c|c|}
\hline \multicolumn{6}{|c|}{ MiMARi MiRAS SEL RISKI ANALIZ FORMU } \\
\hline \multicolumn{3}{|c|}{ YAPI KÜNYESI } & $\begin{array}{c}\text { Risk } \\
\text { PARAMETRELERI }\end{array}$ & Parametre Açıklaması & $\begin{array}{l}\text { RISK } \\
\text { SKORU }\end{array}$ \\
\hline ENV. NO & \multicolumn{2}{|l|}{ YAPI ADI: } & \multirow{3}{*}{ 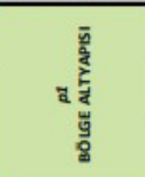 } & $\begin{array}{c}\text { Yapının bulunduğu bölgede altyapı sel suyu tahliyesinde yetersiz. Az yağışta bile } \\
\text { tahliye sorunları yaşanıyor }=5\end{array}$ & \\
\hline iLi & & \multirow[t]{4}{*}{ GENEL TANIM: } & & $\begin{array}{c}\begin{array}{c}\text { Yapının bulunduğu bölgede yağış az olduğunda sorun yaşanmıyor yağıs miktarı } \\
\text { arttığında tahliye sorunları yaçanıyor }=3\end{array} \\
\end{array}$ & \\
\hline iLÇESI & & & & Yapının bulunduğu bölgede altyapı iyi durumda $=1$ & \\
\hline \multirow{2}{*}{\multicolumn{2}{|c|}{ BAKIMINDAN SORUMLU KURULUŞ/Kiși: }} & & \multirow{3}{*}{ « } & $\begin{array}{c}\text { Yapının mimari elemanlanı ve tașryıcıları büyūk oranda kaybedilmiş harap } \\
\text { durumda/ Yapı günümūze kısmen ulașmış / Yapısal hasarlar mevcut = } 5\end{array}$ & \\
\hline & & & & $\begin{array}{l}\begin{array}{l}\text { Yapının bütũnnũ gủnümüze ulaşmıs ancak gözle görülebilen yapısal olamayan } \\
\text { hasarlar mevcut = } 3\end{array} \\
\end{array}$ & \\
\hline ADRESI: & & & & 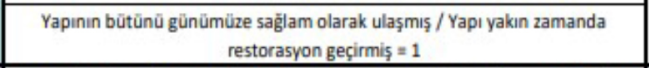 & \\
\hline PAFTA & & \multirow[t]{5}{*}{ YAPININ KONUMU } & \multirow{3}{*}{ 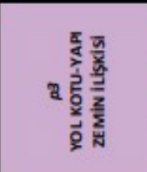 } & $\begin{array}{c}\text { Yapının bodrum katı var / Bodrum katı yok ama yapı giriși yol kotunun 1m'den } \\
\text { fazla altında kalmış }=5\end{array}$ & \\
\hline$A D A$ & & & & $\begin{array}{l}\begin{array}{l}\text { Bodrum kat yok, yapınin girişi yol kotu ile hem zemin veya } 1 \text { metreye kadar yol } \\
\text { kotu altında = } 3\end{array} \\
\end{array}$ & \\
\hline PARSEL & & & & Bodrum kat yok yapının subasmanı var $=1$ & \\
\hline $\begin{array}{l}\text { MIRAS } \\
\text { TÜRÜ }\end{array}$ & & & \multirow{3}{*}{$\underset{2}{2}$} & $\begin{array}{l}\text { Yapı eğimli arazinin bitiş kotunda/azaldığı kotlarda / Yapı dũz arazide su } \\
\text { kaynağı kenarında= } 5\end{array}$ & \\
\hline $\begin{array}{ll}\text { YAPIM } \\
\text { TARIHI/ }\end{array}$ & & & & Yapı eḡimli arazideki yerleşimin orta kotlannda = 3 & \\
\hline \multirow{5}{*}{\multicolumn{3}{|c|}{ YAPI FOTOĞRAFI }} & & Yapı eğimli arazinin üst kotlarında $=1$ & \\
\hline & & & \multirow{3}{*}{ 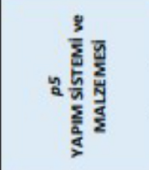 } & Yapım sistemi Ahşap Karkas/ Ahşap Yığma / Kerpiç = 5 & \\
\hline & & & & Kagir yı̃ma (Taş - tuğla) / Metal iskelet sistem $=3$ & \\
\hline & & & & Betonarme $=1$ & \\
\hline & & & \multirow{3}{*}{ \&. } & Yapının bakımından sorumlu kişi/kurum bilinmiyor $=5$ & \\
\hline $\begin{array}{l}\text { ANALIZ } \\
\text { TARIHI }\end{array}$ & & & & $\begin{array}{c}\text { Yapının bakım sorumluluğu birden çok kiş̧/kuruma ait olduğundan karmaşa } \\
\text { olușuyor }=3\end{array}$ & \\
\hline \multirow{7}{*}{\multicolumn{3}{|c|}{ ANALiZ DEĞERLENDIRMESI ve ÖNEMLI NOTLAR }} & & Yapınin bakımından kamu kurumu / mülk sahibi sorumlu =1 & \\
\hline & & & \multirow{2}{*}{ 点 } & Yapıya 5 yildan fazla zamandır bakım yapılmıyor $=5$ & \\
\hline & & & & $\begin{array}{l}\text { Yapıya ihtiyaç oldukça bakım yapılıyor }=3 \\
\text { Yapının her yıl dūzenli olarak bakımları yapılıyor }=1\end{array}$ & \\
\hline & & & \multirow{3}{*}{ 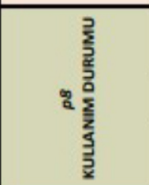 } & Yapi terk edilimiş / atıl / uzun süredir kullanilmıyor = 5 & \\
\hline & & & & $\begin{array}{l}\begin{array}{l}\text { Yapıda gayriresmi kullanıcılar tarafından kullanilıyor / işgal durumunda / } \\
\text { kamuya açik kullanım }=3\end{array} \\
\end{array}$ & \\
\hline & & & & Yapı resmi kullanıcilar /( mülk sahibi tarafından kullanılıyor = 1 & \\
\hline & & & \multirow{3}{*}{ : } & $\begin{array}{c}\text { Su temasl yapilar / Koprư veya müze, arșiv, kutüphane gibl içerisinde su tutucu } \\
\text { ve değerli çok fazla taşınabilir kültür miras varlı̈̆ı barındıran ișlevler / Iş̧levi } \\
\text { devam etmivor veni islevi vok }=5\end{array}$ & \\
\hline \multirow{6}{*}{\multicolumn{3}{|c|}{ ÖNLEM/MÜDAHALE KATEGORISI }} & & $\begin{array}{l}\text { Arkeoljik alan, mezarlık, hazire, şehitlik, vb. işlevlere sahip ve işlevi devam } \\
\text { eden varlıklar (açik hava koşullarına açık işlevler) / Içerisinde fazla hareketli } \\
\text { mobilya ve donatı bulunan işlevler (otel, okul, hastane, resmi daire vb.) = } 3\end{array}$ & \\
\hline & & & & $\begin{array}{c}\text { Yapının işlevi içerisinde fazla hareketli mobilya, donatı vb. olmasını } \\
\text { gerektirmeyen işlevlere sahip yapılar }=1\end{array}$ & \\
\hline & & & \multirow{4}{*}{$\begin{array}{l}\text { SAYISAL } \\
\text { HESAPLAMALAR }\end{array}$} & RISK PARAMETRELERI TOPLAM SKORU & \\
\hline & & & & $\begin{array}{c}\text { RiSKLLi ALAN KATSAYISI } \\
\text { (Yüksek Sel Riskli x } 3 \text { / Orta Sel Riskli } \times 2 \text { / Düșük Sel Riski x1) }\end{array}$ & \\
\hline & & & & SEL RISKI SKORU & \\
\hline & & & & ÖNLEM/MŨDAHALE KATEGORISI & \\
\hline
\end{tabular}

skoru aralığı "çok yüksek, yüksek, orta, düşük, çok düşük" olmak üzere beş risk ölçeğine ayrılmıştır (Tablo 4). Risk düzeyine göre renklendirilen tablo yapının müdahale/önlem kategorisini belirlemek için de kullanılacaktır. Sel önlem ve müdahaleleri "yapısal" ve "yapısal olmayan" olarak ayrılmaktadır ve bunların çoğu ciddi maliyetlere neden olmaktadır. Sel risk düzeyinin belirlenmesi, uygun önlem ve müdahale kararları alınmasında ilk adımı teşkil ederek gereksiz maliyetlerin ortaya çıkmasını da engellemiş olacaktır. 
Tablo 4. Mimari miras sel risk düzeyi tablosu (Gökmen Erdoğan ve Ünal, 2021)

\begin{tabular}{|ll|l|}
\hline Sel riski skor aralığı & Risk düzeyi & Lejant \\
\hline $118-145$ & Çok yüksek & \\
$91-117$ & Yüksek & \\
$64-90$ & Orta & \\
$37-63$ & Düşük & \\
$9-36$ & Çok düşük & \\
\hline
\end{tabular}

\section{MiSRAM ile II. Bayezid Külliyesi Yapılarının Sel Riski Analizi}

Mimari mirasın sel riskini analiz etmek için önerilen model çalışma kapsamında örneklem alan olarak; son yıllarda artan sel sayıları, yüksek sel riskli konumu ve miras değeri nedeniyle Edirne II. Bayezid Külliyesi yapılarına uygulanmıştrr.

\section{Dünü ve Bugünüyle Edirne ve Seller}

Edirne, Osmanlı İmparatorluğu'na başkentlik de yapmış Balkan Yarımadası'nın güneydoğu köşesini teşkil eden Trakya yöresinde, Meriç Nehri'nin Tunca ve Arda ile birleştiği kesiminde Tunca Nehri'nin Meriç'e ulaşmadan önce çizdiği yarım daire şekilli bir yayın içine kurulmuş tarihi bir kenttir (Darkot, 1965). Roma dönemindeki Belgrad-SofyaKonstantinopolis askeri yolunun üzerinde, İstanbul'a yaklaşık 250 kilometre uzaklıkta bulunur. Sahip olduğu taşınmaz kültürel miras ile "tarihi kent" niteliği taşıyan Edirne'de
Dünya Mirası Selimiye Camii ile geçici Dünya Miras Listesindeki II. Bayezid Külliyesi bulunmaktadır.

Kentin üç tarafinı çevreleyen nehirler, tarih boyunca farklı boyutlarda taşkınlarla kentin sürekli sel afetine maruz kalmasına neden olmuştur (Turoğlu ve Uludağ, 2013). Hibri'ye (1996) göre II. Selim döneminde sular 400'den fazla evin yıkılmasına neden olacak kadar yükselmiştir. 1960'।ı yıllarda inşasına başlanan seddeler ${ }^{1}$ kenti uzun yıllar selden korumuş ancak 2000'li yıllarda sel afeti sayısında bir artş̧ olmuştur (Turoğlu ve Uludağ, 2013) (Tablo 5).

İklim değişikliğinin etkileri Meriç Nehri Havzası'nda da görülmektedir. Bulgaristan'da kalan, havzanın yukarı bölümünde meydana gelen sıcaklık ve yağış özelliklerindeki değişiklikler; havzanın Türkiye'deki bölümünde önemli problemlere neden olmaktadır (Turoğlu ve Uludağ, 2015). Araşttrmalara ve kent merkezinde bulunan Kirişhane Gözlem İstasyonu verilerine göre özellikle 2000'li yıllardan sonra Aşağı Meriç Nehri'nde aylık, yıllık ve mevsimlik akımlar taşkın oluşturacak düzeyde artş göstermiş̧tir (Erkal ve Topgül, 2020). Tablo 3'e göre 1509-2000 yılları arasında 36 sel afetine karşılık 2000-2019 yılları arasında 12 sel afeti meydana gelmiştir. Tablo mevsimlere göre incelendiğinde ise geçmiş sel afetlerinin yaz aylarında meydana gelmezken 2010 yılından sonraki sel afetlerinin yaz aylarında meydana gelmesi iklim değişikliği açısından dikkati çekmektedir. Bununla birlikte 2005 ve 2006 yıllarında meydana gelen taşkınlarda seddelerde yırtılmaların meydana gelmesi (Erkal ve Topgül, 2014) sel afeti sayısındaki artı̧

Tablo 5. Yıllara göre Edirne sel afetleri (Gökmen Erdoğan ve Ünal, 2021)

\begin{tabular}{|c|c|c|c|}
\hline \multicolumn{4}{|c|}{ EDIRNE'DE MEYDANA GELMIŞ SEL AFETLERI } \\
\hline Eylül 1509 & 5 Mart 1946 & \multicolumn{2}{|c|}{$15-24$ Şubat 2005} \\
\hline 1571 & 29 Ocak 1947 & \multicolumn{2}{|c|}{7 Ocak 2006} \\
\hline 1657 & 15 Şubat 1947 & \multicolumn{2}{|c|}{20 Kasım 2007} \\
\hline Ocak 1747 & 4-5 Mart 1950 & \multicolumn{2}{|c|}{ 13-16 Şubat 2010} \\
\hline 18 Ocak 1845 & 6 Kasım 1950 & \multicolumn{2}{|c|}{7 Şubat 2012} \\
\hline 7 Kasım 1857 & 10 Ekim 1953 & \multicolumn{2}{|c|}{16 Temmuz 2014} \\
\hline 26 Ocak 1863 & 5 Mart 1954 & \multicolumn{2}{|c|}{ Şubat 2015} \\
\hline Aralık 1894 & 20-21 Kasım 1954 & \multicolumn{2}{|c|}{ Ocak 2016} \\
\hline 10 Ocak 1896 & 11 Ocak 1955 & \multicolumn{2}{|c|}{ Haziran 2017} \\
\hline Mayıs-Haziran 1897 & Ocak-Şubat 1956 & \multicolumn{2}{|c|}{ Aralık 2017} \\
\hline 13 Mart 1929 & 22 Mayıs 1956 & \multicolumn{2}{|c|}{ Kasım 2018} \\
\hline 17-27 Şubat 1931 & 30 Aralık 1960 & \multicolumn{2}{|c|}{ Ağustos 2019} \\
\hline 14 Aralık 1931 & 2 Kasım 1962 & \multirow{6}{*}{ ilkbahar: } & \multirow{6}{*}{ Yaz: } \\
\hline Mart 1936 & 3-10 Şubat 1963 & & \\
\hline 13 Şubat 1937 & 8-9 Aralık 1966 & & \\
\hline 27 Ocak 1940 & 13-23 Ocak 1981 & & \\
\hline 13 Kasım 1940 & 6-7 Şubat 1981 & & \\
\hline 21 Aralık 1940 & 6-10 Mart 1984 & & \\
\hline \multicolumn{2}{|c|}{ 1509-2000 yılları arasında Edirne'de meydana gelen sel afeti sayısı: 36} & \multicolumn{2}{|c|}{$\begin{array}{l}\text { 2000-2019 yılları arasında Edirne'de } \\
\text { meydana gelen sel afeti sayısı: } 12\end{array}$} \\
\hline
\end{tabular}

Sedde: Akarsu boyunca suyu belli sınırlar içinde tutmak için veya dalga ve

gelgit taşkınlarından korunmak için inşa edilmiş yapay dolgu (URL11). 
ve iklim değişikliği hesaba katıldığında; Edirne'nin, mimari miras varlıklarının sel hasarı açısından risk altında olduğu düşünülmektedir.

\section{Bayezid Külliyesi}

Edirne'de II. Bayezid tarafindan Mimar Hayrettin'e yaptrılan külliyenin inşaatına (Aslanapa, 1965) Kili ve Akkerman fethine giderken II. Bayezid ordunun ihtiyaçlarını gözden geçirmek üzere Edirne'de kaldığında, kentin önde gelenlerinin şehrin hastane ihtiyacını padişaha arz etmesi ile 23 Mayıs 1484 Cuma günü başlanmıştır (Şehsuvaroğlu, 1965; Tosyaviazade, 1998). Tunca Nehri'nin kuzey kıyısında akarsuyun hemen kenarında cami, hastane, medrese, imaret, tabhane, hamam, değirmen ve köprüden oluşan külliye inşaat 1488 yılında tamamlanmıștır (Aslanapa, 1965; Şahsuvaroğlu, 1965; Eyice, 1992). Külliyenin bir diğer yapısı bu bölgeyi şehre bağlayan taş köprüdür (Şekil 5) (Eyice, 1992). Hamam ve değirmen günümüze ulaşmamıştır.

Külliye, 22 bin metrekarelik bir alana kurulmuş ve çevresi bir ihata duvarıyla kuşatılmıştır (Şekil 6). Külliye binaları düzgün kesme taşla inşa edilmiştir; mutfak ve depoları külliyenin kuzeydoğusunda bulunmaktadır (Şekil 7). Dikdörtgen planlı mutfak, kare biçimli bir avlunun etrafindaki 11 kubbe ile örtülen bölümlerden oluşmaktadır (URL9).

II. Bayezid Külliyesi yapıları konumları nedeniyle Şekil 8 ve Şekil 9'da görüldüğü gibi tarih boyunca taşkın sularına maruz kalmıştır. 2015 yılında meydana gelen selde, sel sularının Külliye önündeki seddelerden sızınt yaptığı gözlenmiştir.

II. Bayezid Camii ve Tabhaneleri: Üç taraftan girişi olan cami avlusu kubbeli revaklarla çevrilmiştir. Günümüzde

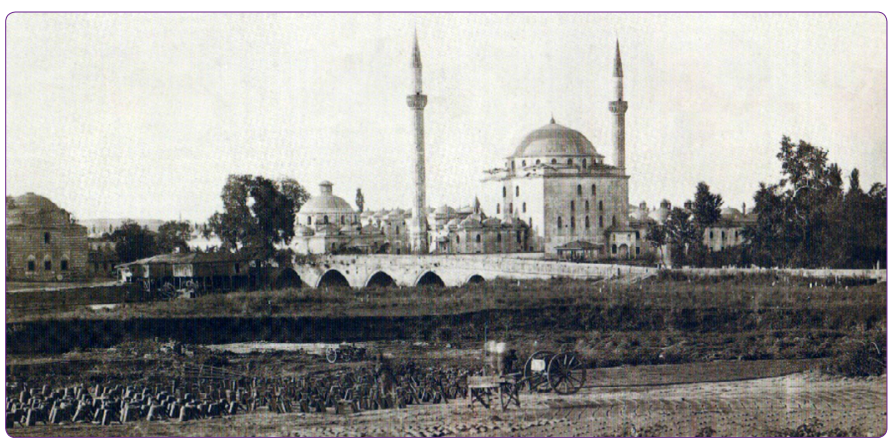

Şekil 5. 1890'lar II. Bayezid Külliyesi ve taş köprü (Özendes, 1999, s. 148).

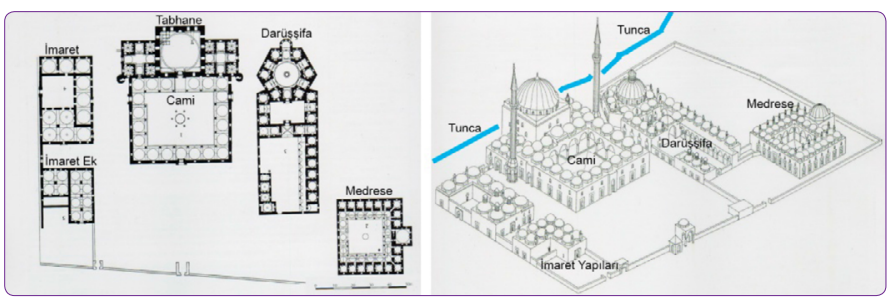

Şekil 6. Günümüzde külliye yapıları plan (sol) genel görünüm (sağ) (T.C. Edirne Valiliği, 2013).

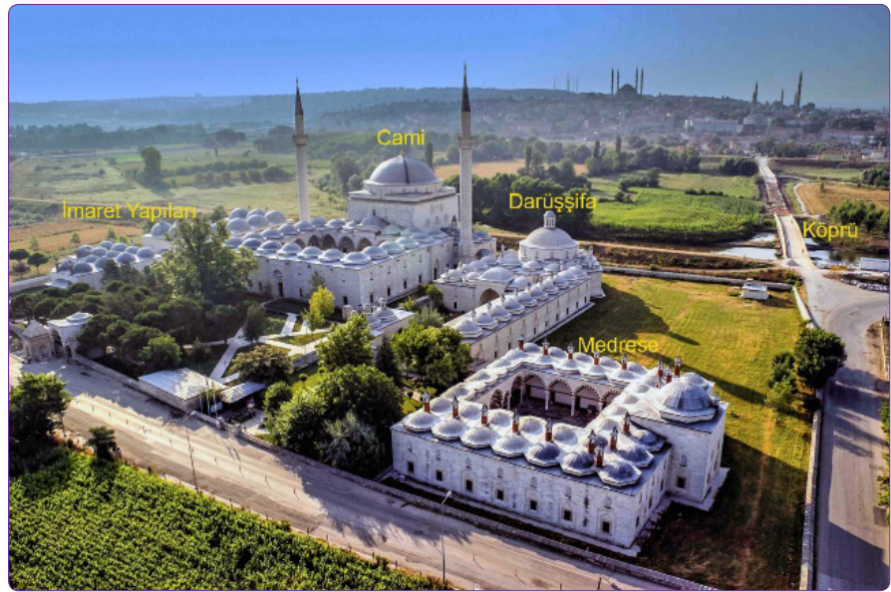

Şekil 7. Külliye yapıları günümüz genel görünüm (URL9).

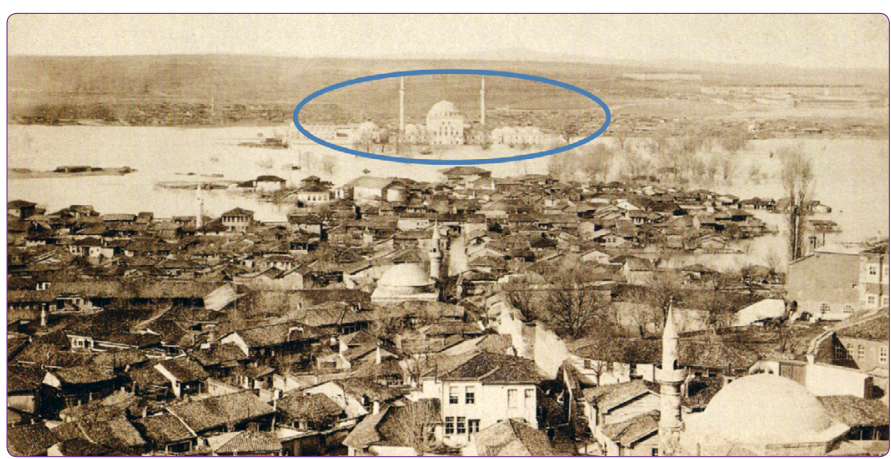

Şekil 8. D. Michailides'e ait 1894 seli sonrası II. Bayezid Külliyesi fotoğrafı (Özendes, 1999, s. 142).

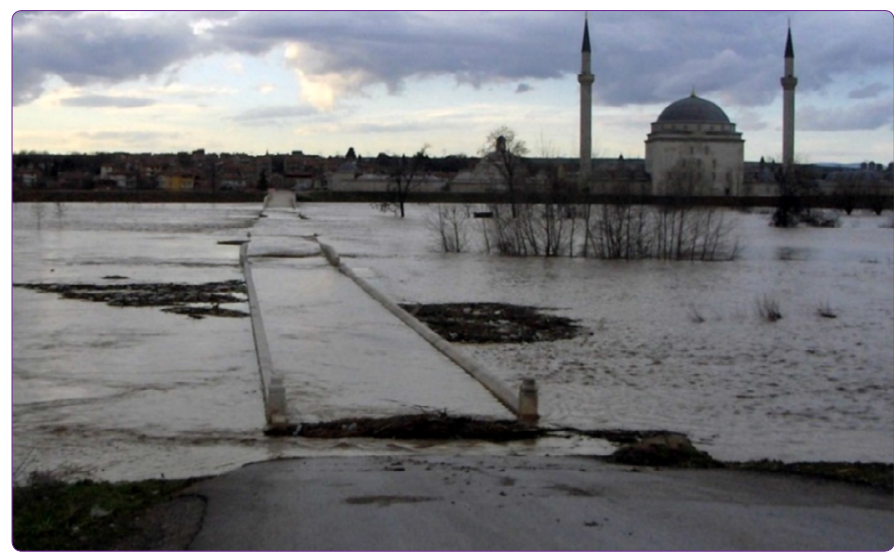

Şekil 9. 2015 yılı sel sonrası sular altında kalan tarihi köprü ve II. Bayezid Külliyesi (Büktel Arşivi, 2015). ${ }^{2}$

üstü açık olan mermer şadırvanın geçmişte üstünde bir saçağı olduğu düşünülmektedir. (Eyice, 1992). Bayezid Camii, 22 metre çapında kubbesi dört duvarına oturan içten kemersiz ve sütunsuz kare formundadır. Caminin dokuzar kubbeli ve dörder odalı yan duvarlara bitişik iki tabhanesi vardır (Tosyavizade, 1998). Beyazıt Camii'nin çifte mi-

Fotoğraf, Trakya Üniversitesi Edebiyat Fakültesi Öğretim Üyesi Doç. Dr. Yılmaz Büktel'in kişisel arşivinden alınmıştır. 


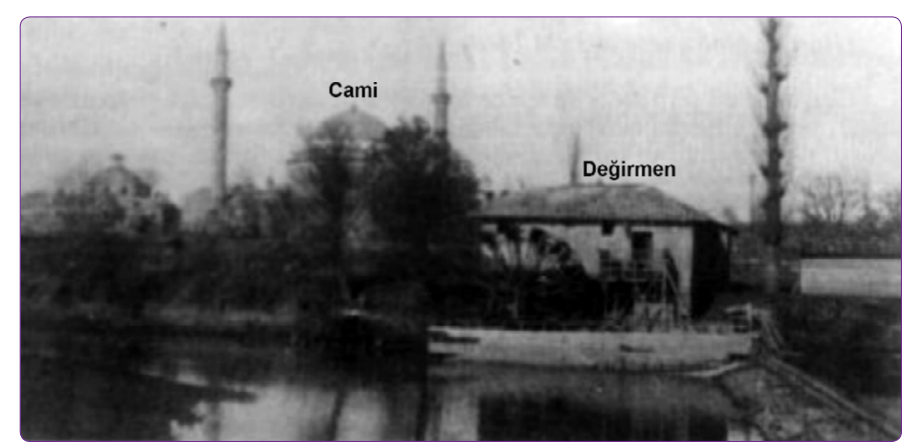

Şekil 10. Günümüze ulaşmamış olan Yalnızgöz Değirmeni görünümü 1917 (Tosyavizade, 1999, s. 70).

naresi, iki yanlardaki tabhanelerin dış köşelerindedir ve Evliya Çelebi'ye göre minarelerin cami kütlesinden uzak olmasının nedeni depremde yıkılırlarsa kubbeye zarar vermemeleridir (Eyice, 1992). Mermer ayaklar üzerindeki padişah mahfeli Edirne camilerinde yapılan ilk mahfeldir (Tosyavizade, 1998). Kaynaklarda caminin mihrabı önünde padişahların Cuma namazı kılmak için nehirden kayıklarla geldiğinde kullandığı bir rıhtımdan bahsedilmektedir (Tosyavizade, 1999). Ancak günümüzde rıhtımın izine rastlanmamıştr. Tosyavizade (1999) cümle kapı kanatlarının şiddetli taşkınlarda caminin içine bir arşın yüksekliğinde su girdiği için su içinde kalan kanat kısımlarının çürüdüğünü belirtmiştir. Eyice de (1992) caminin geçmeli kapı kanatlarının Türk ağaç işçiliğinin güzel örnekleri olup taşkınlarda uzun süre su içinde kaldıklarından alt kısımlarının çürüdüğünü ve korunması için Edirne müzesine kaldırıldığını ifade etmiştir.

Darüşşifa (Hastane): Hastane; hastalar, görevliler, akıl hastaları ve hizmet kısımları olmak üzere dört ayrı bölümden oluşmaktadır. Hastalar kısmı, yüksek ve büyük bir kubbenin altındaki, az sayıda hasta bakıcı ile kolay kontrol sağlayan daire şeklindeki mermerliğin etrafina dizilmiş odalar ve sofalardan oluşmaktadır (Tosyavizade, 1998). Tosyavizade'ye (1998) göre o yüzyılda başka ülkelerde akıl hastaları yakılırken, II. Bayezid Külliyesi kapsamında cami ile beraber ruh hastalıkları evi ve hastanesi yapılması, dönemi için ileri bir yaklaşımdır; kubbesi 30 metre çapında olan hastanenin altı odası ve beş sofası bulunmaktadır. Osmanlı devri hayır binaları arasında apayrı bir yeri olan darüşşifa, mimarisi bakımından ilgi çekicidir. Vakfiyesinde bahsedilmemekle birlikte Evliya Çelebi'ye göre, akıl hastalarının mûsiki ile tedavi gördüğü II. Bayezid Darüşşifası, Balkan Harbi sırasında kapanarak harap olmaya terk edilmiştir (Eyice, 1992). Darüşşifa, Türk hastane mimarisinin başka bir benzeri olmayan çok değerli bir eseridir (Eyice, 1992, s. 44) ve günümüzde Trakya Üniversitesi bünyesinde medrese ile beraber Sağlık Müzesi olarak kullanılmaktadır.

Medrese: Kaynaklarda Medrese-i Etibba olarak da geçen tıp medresesi, cami dış avlusunun sağında yer almaktadır (Tosyavizade, 1998; Eyice, 1992). Kubbeli, revaklı bir şadırvan avlusunu çevreleyen kubbeli 18 hücreden ve ortada bir dershaneden meydana gelmiştir (Eyice, 1992). Tamamen terk edilmeden bir süre önce askeri tutukevi olarak da kullanılmıştır (Tosyavizade, 1998).

İmaret: Eyice'ye (1992) göre personelin yanı sıra tabhanelerde misafir edilenler, medresede barınan öğrenciler, darüşşifada tedavi edilen hastalarla beraber vakıfta hayli kalabalık bir topluluk bulunmaktadır ve bunlar için külliyenin dış avlusunun sol tarafina aşhane-imaret tesisleri inşa edilmiştir. Ancak aşhane-imaret yapılarını teşkil eden bölüm ve mekânların gerçek fonksiyonları tam olarak anlaşılamamaktadır (Eyice, 1992). İmaretin kuzeybatı tarafinda ocaklarından mutfak olduğu anlaşılan kare bir mekân ve ona bitişik olmakla birlikte aralarında bağlant olmayan sekiz kubbeli bazı kaynaklarca ahır olduğu iddia edilen bir mekân daha vardır (Eyice, 1992). Bu mekânlar çalışmada imaret ek yapılar olarak tanımlanmıştır. Günümüzde Trakya Üniversitesi'nin kullanımındadır.

II. Bayezid Köprüsü: Eyice'ye (1992) göre kitabesi bulunmayan köprü, külliyenin şehirle bağlantısını sağlamak üzere aynı yıllarda (1484-1488) külliyenin bir parçası olarak yapılmıştır ve bu nedenle "Yeni İmaret Köprüsü" adıyla da anılmaktadır. Yakın semtlerdeki halkın camiye gelmesini kolaylaşttrmak ve cemaat sayısını artırmak amacıyla inşa edildiği belirtilen (Köylüoğlu, 2001) muntazam işlenmiş kesme taş Beyazıt Köprüsü'nün alt büyük ve sivri kemerli gözü vardır; yanlarda iki tahliye gözü ve tabliyesinin iki yanında aynı taştan işlenmiş korkuluklar uzanır (Eyice, 1992). Köprünün sol tarafinda iki değirmen ve kendi dönen (nehir akış gücüyle) dolap günümüze ulaşamamıştır (Köylüoğlu, 2001) (Şekil 10).

\section{MiSRAM ile II. Bayezid Külliyesi Yapılarının Sel Riskinin Analizi}

Edirne'de 2000'li yıllardan sonra sellerin sayısında bir artış olduğu sayısal verilerden anlaşılmaktadır (Tablo 5). Taşkın önlemede kullanılan yapısal önlemlerden yazlık ve kışlık seddeler Şekil 11'de görüldüğü gibi nehirlerin farklı debilerine göre taşkın sularını nehir yatağında tutmaya yö-

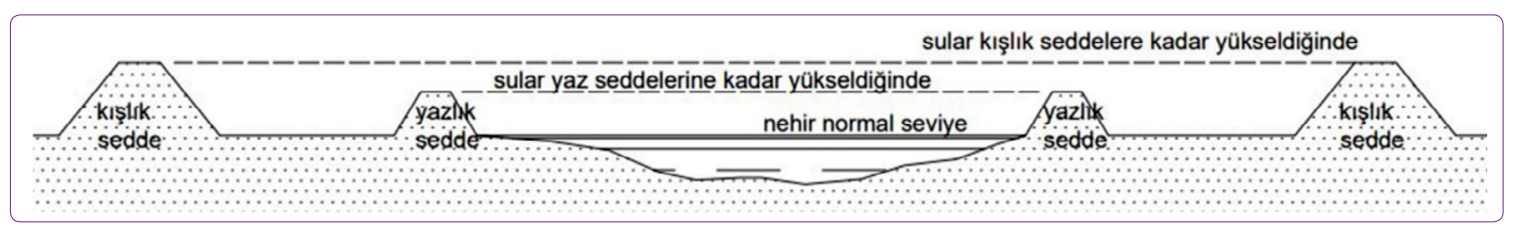

Şekil 11. Seddelerin şematik gösterimi (Gökmen Erdoğan ve Ünal, 2021). 


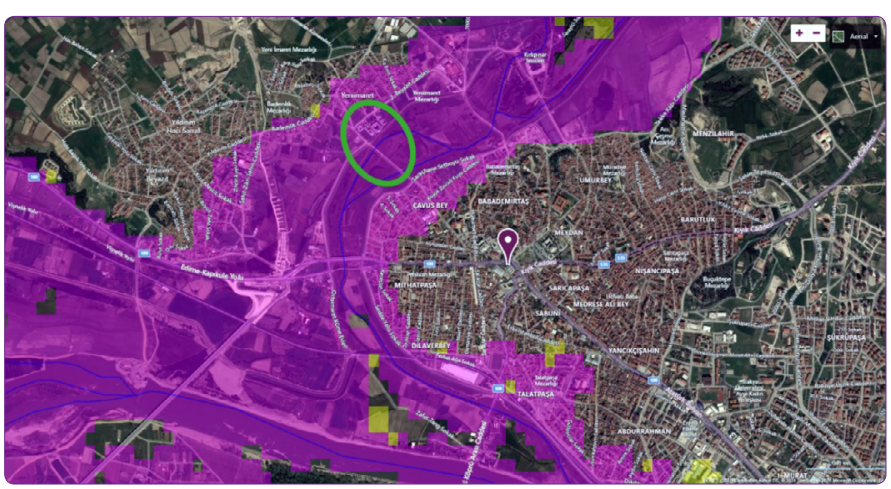

Şekil 12. Edirne sel riski yüksek alanlar (FM Global - URL8).

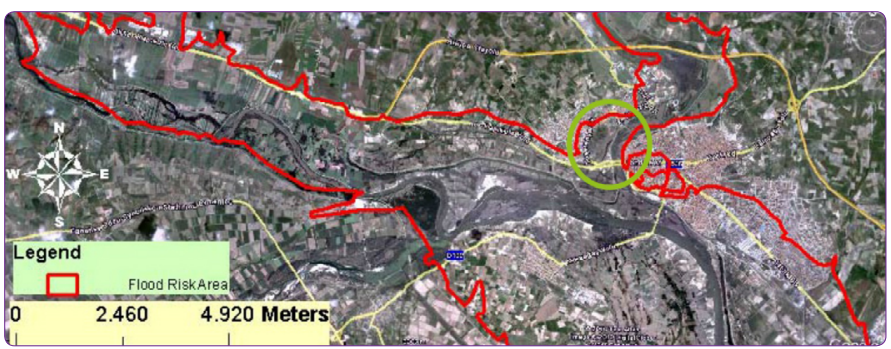

Şekil 13. Edirne Merkez sel riskli alanlar (Turoğlu ve Uludağ, 2010).

nelik olarak inşa edilmektedir. Edirne'de yoğun taşkınların verdiği hasarı önlemeye yönelik 1960'lı yıllarda inşasına başlanan yazlık ve kışlık seddelerde 2006 ve 2015 yıllarında yargınlar oluşması kent merkezini uzun yıllardır selden koruyan seddelerle ilgili endişeler ortaya çıkarmaktadır (Akkaya, 2016).

Çalışma kapsamında cami, darüşşifa, medrese, imaret, imaret ek yapıları ve köprü olmak üzere alt yapının sel riski, geliştirilen modelle analiz edilmiştir. "Mimari Miras Sel Riski Analiz Formu" her yapı için yerinde doldurularak

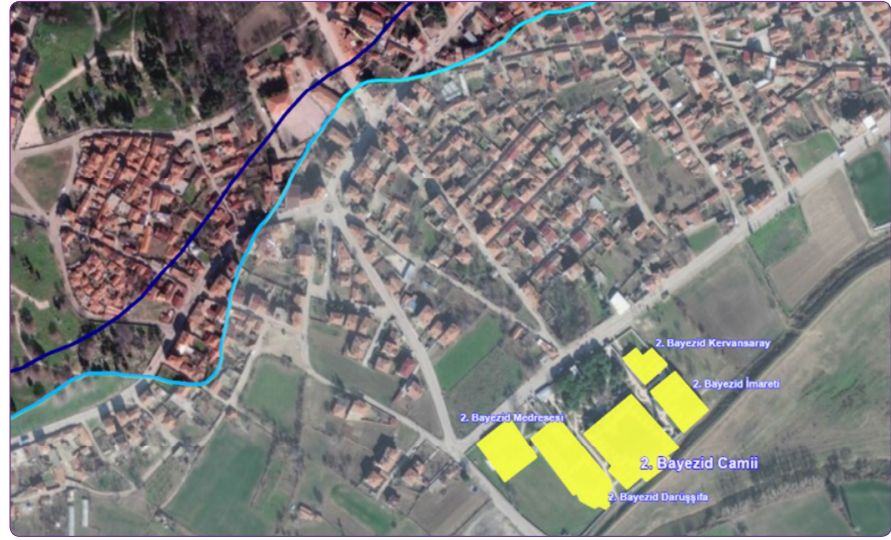

Şekil 14. Örneklem alan ArcGIS Online (URL12) sel risk haritası (Gökmen Erdoğan ve Ünal, 2021).

yapıların risk skoru elde edilmiştir (Tablo 6). Taşkının sebebiyet vereceği zararlar su seviyesine ve yayılma alanına bağlıdır (Akkaya, 2016). Bölge için hazırlanmış sel risk haritaları (Şekil 12), geçmiş sel kayıtları ve havadan görüntüler ile alanın sel riskine yönelik akademik çalışmalardaki sınırlar (Şekil 13) karşılaştırmalı olarak incelenmiş ve ArcGIS uygulamasında sel riskli alan sınırları işaretlenmiştir (Şekil 14). Külliye yapılarının bulunduğu bölgenin tüm verilerde sel riski yüksek olarak verildiğinden sel riskli alan katsayısı "yüksek" (x3) olarak belirlenmiştir.

Sel riskli alan katsayısı ile yapıların toplam risk parametre skorları Tablo 4'te görüldüğü gibi çarpılarak yapıların sel risk düzeyi belirlenmiştir. Bu düzey aynı zamanda önlem/ müdahale kategorisini göstermektedir. Buna göre yapıların bulunduğu bölgede altyapı yetersizliği selde hasar görme riskini artırmaktadır. Bununla birlikte yapılar, sel riski yüksek bölgede bulunmalarına rağmen köprü haricinde risk düzeyleri "orta" olarak tespit edilmiştir. Köprünün riski ise

Tablo 6. II. Bayezid Külliyesi yapılarının sel riski analiz sonuçları (Gökmen Erdoğan ve Ünal, 2021)

\begin{tabular}{|c|c|c|c|c|c|c|}
\hline Risk Parametrelerí & Cami & $\begin{array}{l}\text { Hastane } \\
\text { (Darüşşifa) }\end{array}$ & $\begin{array}{l}\text { Tıp } \\
\text { Medresesi }\end{array}$ & imaret & $\begin{array}{l}\text { imaret ek } \\
\text { yapı }\end{array}$ & Köprü \\
\hline p1. altyapı & 5 & 5 & 5 & 5 & 5 & 5 \\
\hline p2. sağlamlık & 1 & 1 & 1 & 1 & 1 & 3 \\
\hline p3. zemin-yol kotu ilişkisi & 3 & 3 & 3 & 3 & 3 & 5 \\
\hline p4. konum & 5 & 5 & 5 & 5 & 5 & 5 \\
\hline p5. yapım sistemi ml. & 3 & 3 & 3 & 3 & 3 & 3 \\
\hline p6. bakım sorumluluğu & 1 & 1 & 1 & 1 & 1 & 1 \\
\hline p7. bakım durumu & 3 & 1 & 1 & 3 & 3 & 5 \\
\hline p8. kullanım durumu & 1 & 1 & 1 & 1 & 1 & 1 \\
\hline p9. işlev & 1 & 5 & 5 & 1 & 1 & 5 \\
\hline$\sum \boldsymbol{p}$ (parametreler top.) & 23 & 25 & 25 & 23 & 23 & 33 \\
\hline$\overline{R S}=\Sigma P \mathrm{PRK}$ & X3 = 69 & $\mathrm{X3}=75$ & $\mathrm{X} 3=75$ & $X 3=69$ & X3 = 69 & X3 = 99 \\
\hline SEL RISK DÜZEYI & ORTA & ORTA & ORTA & ORTA & ORTA & YÜKSEK \\
\hline
\end{tabular}


yüksektir. Bu sonuca göre külliye yapıları için sel yönetim planlaması yapılırken köprü ayrıca değerlendirilmelidir.

\section{Değerlendirme ve Sonuç}

Mimari mirasın sel riskinin bilinmemesi, gerekli ve etkin önlemlerin alınmamasına neden olmakta ve sel kaynaklı hasarları artırmaktadır. İklim değişikliğinin sellerde artş yönünde etkisine bağlı olarak gelecekte sel kaynaklı mimari miras hasarlarının ve kayıplarının artacağı öngörülmektedir. Bu problem ekseninde yürütülen çalışmada;

- iklim değişikliğinin ani ve şiddetli yağışlarda ve buna bağlı olarak sellerde artışa neden olduğu ve gelecekte bu etkilerin artmaya devam edeceği,

- Bilimsel alanda dünyada konuya ilginin arttğı ancak Türkiye'de henüz yeterli farkındalığın oluşmadığı,

- Sel risk katsayısı aynı olan bölgede yer alan miras varlıklarının farklı parametrelere bağlı olarak farklı sel risk düzeylerine sahip olabileceği,

- Mimari mirasta sel hasarını artiran faktörlerin tespit edilerek risk analizinde hesaplamaya katılması gerektiği,

- Mimari mirasın sel riskinin sadece bulunduğu bölgenin sel riski üzerinden hesaplanamayacağı, mimari mirasa özel bir risk analiz modeli geliştirilmesi ve geliştirilen modelde yapının kendi özellikleri ve mevcut durumunun analizde yer alması gerektiği,

- Edirne ilinde sellerin sayısında 2000'li yıllardan sonra belirgin bir artş̧ olduğu bulgularına ulaşılmıştır.

Elde edilen bulgular ışığında çalışma kapsamında geliştirilen MiSRAM; açık, anlaşılır ve kolay uygulanabilir bir modeldir. Sel riski yönetim planlarına entegre edilerek kullanılması halinde, ulusal ve yerel düzeyde koruma için ayrılan kaynakların verimli ve etkin kullanımına katkı sağlayacaktır. Bununla birlikte II. Bayezid Külliyesi yapılarına uygulanarak örneklenen model; alanda daha önce geliştirilmiş örnekler olmadığı için farklılıklar ve eksiklikler açısından kıyaslanamamıştr. Modelin bir diğer zayıf yönü ise uygulamada ihtiyaç duyulan sel riskli alan verilerinin ülkemizde kentsel ölçekte yapılmıyor olması nedeniyle ilgili verilerin zor temin edilmesi ve güvenilirliğinin yeterli olmamasıdır.

Mimari mirasın sel yönetimi planlamasında sel risk analizi, korumada zaten kısıtlı olan kaynakların etkin kullanılması için ilk ve en önemli aşamalardan biridir. Gelecek çalışmalar için sel riski analiz edilmiş miras için, koruma yöntemleri geliştirilmesi ve mimari miras dışında kalan diğer kültürel mirasın sel riskini analiz etmeye yönelik çalışmalar yapılması önerilmektedir.

\section{Kaynaklar}

Akkaya, U. (2016) Meriç ve Tunca Nehirlerinin Edirne Şehir Merkezi Kısmında 2 Boyutlu Taşkın Modellemesi, (Yayınlanmamış Doktora Tezi), Sakarya Üniversitesi, FBE.
Arnbjerg-Nielsen, K., Willems, P., Olsson, J., Beecham, S., Pathirana, A., Bu“low Gregersen, I., Madsen, H. ve Nguyen VTV (2013). Impacts of climate change on rainfall extremes and urban drainage systems: a review, Water Science Technology, 68 (1), s. 16-28.

Aslanapa, O., (1965). Edirne'de Türk Mimarisinin Gelişmesi, Edirne: Edirne'nin 600. Fetih Yıldönümü Armağan Kitabı, Türk Tarih Kurumu Basımevi, Ankara.

Bedeaux, D., Amsing, E., Wout, T. ve Augustyn, A. M., (2018). Is cultural heritage life saving?, Annual Conference of the International Association for Impact Assessment, 16-19 May, Durban, Güney Afrika

Brommelle, N. S., (1970). The Restoration of Damaged Art Treasures in Florence and Venice, Journal of the Royal Society of Arts, Vol. 118, No. 5165, s. 260-269.

Chelariu, O. E., Romanescu, G., lonuț, M., Iosub, M., Enea, A. ve Sandu, I. (2016). Flood susceptibility analysis of the cultural heritage in the Sucevita catchment (Romania), International Journal of Conservation Science, Volume 7, Issue 2, NisanHaziran 2016, s. 501-510.

Çelik, S., Bölük, E., Akbaş, A. İ. ve Deniz, A. (2017). “iklim Değişiyor, Hava Olayları Sertleşiyor", Meteoroloji Genel Müdürlüğü. https://www.mgm.gov.tr/FILES/genel/makale/iklimdegisiyor.pdf

Darkot, B., (1965). Edirne II. Bayezid Külliyesi, Edirne Edirne'nin 600. Fetih Yıldönümü Armağan Kitabı, Türk Tarih Kurumu Basımevi, Ankara.

Dassanayake, D., Burzel, A. ve Oumeraci, H. (2012). Evaluation of Cultural Losses, XtremRisK Project Report.

Daungthima, W. ve Kazunorib, H. (2013). Assessing the flood impacts and the cultural properties vulnerabilities in Ayutthaya, Thailand, Procedia Environmental Sciences, 17 s. 739-748.

Demircan, M., Gürkan, H., Eskioğlu, O., Arabacı, H. ve Coşkun, M. (2017). Climate Change Projections for Turkey: Three Models and Two Scenarios, Turkish Journal Of Water Science \& Management, Volume 1- Issue 1. http://dergipark.gov.tr/download/article-file/282505

Deschaux, J. (2017). Flood-related Impacts on Cultural Heritage, Floods: Volume 1 - Risk Knowledge, (ed. Vinet, F.), ISTE PressElsevier.

Drdacky, M. ve Slizkova, Z. (2007). Flood and post-flood performance of historic stone arch bridges, 5th International Conference on Arch Bridge, 12-14 Eylül, Madeira, Portekiz.

Drdacky, M., Binda, L., Herle, I., Lanza, L. G., Maxwell, I. ve Pospíšil, S., (2007). Protecting the Cultural Heritage from Natural Disasters, European Parliament, Brussels.

Drdacky, M., Binda, L., Hennen, I. C., Köpp, C., Lanza, L. G. and Helmerich, R. (2010a). CHEF Cultural Heritage Protection against Flooding, Institute of Theoretical and Applied Mechanics AS CR, Prague.

Drdacky, M., Herle, I., Drdácký, T. ve Kruschwitz, S. (2010b). Typical damage to cultural heritage in relation to flood events, CHEF Cultural Heritage Protection against Flooding, Institute of Theoretical and Applied Mechanics AS CR, Prague.

EEA (2020). Europe Environment Agency, Report No: 12/2020 https://www.eea.europa.eu/publications/urban-adaptationin-europe

English Heritage, (2010). Flooding and Historic Buildings.

Eriç, M. (1994). Yapı Fiziği ve Malzemesi, Literatür Yayıncılık, İstanbul. 
Erkal, T. ve Topgül, i.., (2014). Meriç Nehri'nin Son 15 Yıllık Taşkınları ve Korunma Projeleri, TÜCAUM VIII. Coğrafya Sempozyumu, 23-24 Ekim, Ankara Üniversitesi, Ankara.

Erkal, T. ve Topgül, I.,, (2020). Aşağı Meriç Nehri Akımlarının Mevsimsel Ve Yıllık Değişiminin Taşkınlar Üzerine Etkisi, Türk Coğrafya Dergisi, 74 (2020) 33-38, Türk Coğrafya Kurumu. https://dergipark.org.tr/tr/download/article-file/1173363

Eyice, S., (1992), Beyazıt II Camii Ve Külliyesi, Türkiye Diyanet Vakfi İslam Ansiklopedisi, 6. Cilt, s: 42-45, TDV Yayınları, İstanbul.

Farmer, G. T. ve Cook J. (2013). “Climate Change Science: A Modern Synthesis", Springer Dordrecht Heidelberg New York London ISBN 978-94-007-5756-1 ISBN 978-94-007-5757-8 (eBook)

Fidler, J., Wood, C. and Ridout, B. (2004). Flooding and Historic Buildings Technical Advice Note, English Heritage.

Galloway, G., Seminara, G., Blöschl, G., Garcia, M., Montanari, A., ve Solari, L. (2017) Report of the International Technical and Scientific Committee of Florence 2016 on the Protection of Florence From Flooding, Frienze Press. ISBN 978-88-6453677-4.

Gandini, A., Egusquiza, A., Garmendia, L. ve San-José, J. (2018). Vulnerability assessment of cultural heritage sites towards flooding events, Florence Heri-Tech - The Future of Heritage Science and Technologies, IOP Conf. Series: Materials Science and Engineering, 364 012028, IOP Publishing.

Hibri, A. (1996). "Enisü'l-Müsamirin Edirne Tarihi 1360-1650", (Çev. Kazancıgil, R.), Türk Kütüphaneciler Derneği, Edirne Şubesi.

Historic Preservation Division, (1997). After the Flood: Rebuilding Communities Through Historic Preservation, Georgia Department of National Resources, USA. https://www.dca. ga.gov/sites/default/files/afterthefloodtwo.pdf

IPCC, (2018). "Special Report: Global Warming of $1.5^{\circ} \mathrm{C}$ ”. https:// www.ipcc.ch/sr15/chapter/chapter-1/

Jirásek, P. (2003) "Natural Disaster Cooperation and Solution (Floods in Prague 2002)", Cultural Heritage Disaster Preparedness and Response International Symposium, 23-27 Kasım, Hyderabad, India.

Jha, A. K., Bloch, R. ve Lamond, J. (2012). Cities and Flooding A Guide to Integrated Urban Flood Risk Management for the 21st Century, GFDRR, The World Bank, Washington, D.C.

Kadıoğlu, M. (2007). “iklim Değişiklikleri ve Etkileri: Meteorolojik Afetler", TBMM Afet Sempozyumu Bildiri Kitabı, ss:47-55.

Köylüoğlu, N. M., (2001). Edirne'de Osmanlıdan Günümüze Su Yapıları, Türk Kütüphaneciler Derneği Yayınları, Edirne.

Kurnaz, L. (2019). Son Buzul Erimeden: İklim Değişikliği Hakkında Merak Ettiğiniz Herşey, Doğan Egmont Yayıncılık, İstanbul, Türkiye.

Lanza, S. G., (2003). Flood hazard threat on cultural heritage in town of Genoa (Italy), Journal of Cultural Heritage, 4, s:159167.

Li, H., Zhang, J., Sun, J. ve Wang, J., (2017). A Visual Analytics Approach for Flood Risk Analysis and Decision-making in Cultural Heritage, Journal of Visual Languages \& Computing. 41. 10.1016/j.jvlc.2017.05.001.

Lollino G. ve Audisio, C. (2006) "UNESCO World Heritage sites in Italy affected by geological problems, specifically landslide and flood hazard", Landslides, 3:311-321 Springer-Verlag

\section{DOI 10.1007/s10346-006-0059-7}

Mikule, M. (2004), "Looking Back: The Floods and Their Impact on the Czech Cultural Heritage", Prague. https://www. radio.cz/en/section/arts/looking-back-the-floods-and-theirimpact-on-the- czech-culturalheritage

National Trust for Historic Preservation, (2005). Treatment of Flood-Damaged Older and Historic Buildings, Preservation Books, Washington, D.C.

Nedvědová, K. (2013). Cultural Heritage and Flood Need of Interdisciplinarity http://dx.doi.org/10.4236/jwarp.2013.54A004

Nedvědová K. ve Pergl, R. (2013). Cultural Heritage and Floods Risk Preparedness, Journal of Water Resource and Protection, 5, 21-24.

Ortiz R, Ortiz P, Martín J.M. ve Vázquez M.A. (2016). A new approach to the assessment of flooding and dampness hazards in cultural heritage, applied to the historic centre of Seville (Spain), Science of the Total Environment, 2016 May 1; s. 551-552, 546-55.

Özendes, E. (1999). Osmanlı'nın İkinci Başkenti Edirne, Yapı-endüstri Merkezi, İstanbul. ISBN: 975-7438-80-4.

Risk Management Solutions, (2002). Central Europe Flooding, August 2002, Event Report. http://forms2.rms.com/rs/729DJX-565/images/fl_2002_central_europe_flooding.pdf

Pelling, M., (2011) Adaptation to climate change: from resilience to transformation. Routledge, London.

Pickles, D., (2015). Flooding and Historic Buildings, Historic England, UK.

Snow, J., (2014). Flood Damage to Traditional Buildings, Historic Scotland, Edinburg.

Spennemann, D. H. R. (1999). "Cultural Heritage Conservation During Emergency Management: Luxury or Necessity?" International Journal of Public Administration, 22 (5), s. 745804 https://doi.org/10.1080/01900699908525403

Stovel, H. (1998). Risk Preparedness: A Management Manual for World Cultural Heritage, ICCROM, ISBN 92-9077-152-6.

Şehsuvaroğlu, B. N., (1965). Edirne II. Bayezid Külliyesi, Edirne Edirne'nin 600. Fetih Yıldönümü Armağan Kitabı, Türk Tarih Kurumu Basımevi, Ankara.

T.C. Çevre ve Şehircilik Bakanlığı (2012). "Türkiye'de İklim Değişikliği Risk Yönetimi", Ankara.

T.C. Edirne Valiliği, (2013). Edirne Taşınmaz Kültür Varlıkları Envanteri, Cilt 1, ISBN: 978-605-63975-61.

Tosyavizade, R. O., (1998). Edirne Rehnüması (Edirne Şehir Klavuzu), Çev. Kazancıgil, R., Trakya Üniversitesi Rektörlüğü Yayınları No: 11, Edirne.

Tosyavizade, R. O., (1999). Edirne Evkaf-ı İslamiyye Tarihi 1. Cilt: Camiler ve Mescitler, Çev. Özsoy Ü., Vakıflar Genel Müdürlüğü Yayınları, Ankara.

Turoğlu, H. ve Uludağ, M. (2010). Floods and Flashfloods in Edirne, 10th International Multidisciplinary Scientific Geoconference SGEM2010, 20-26 June, Bulgaria.

Turoğlu, H. ve Uludağ, M., (2013) “Arşiv Verilerine Dayalı Ön Değerlendirme: Edirne'de Meydana Gelen Eski ve Güncel Taşkınlar", Prof. Dr. Asaf Koçman?a Armağan, Ege Ü. Edebiyat Fak. Yayın, Sayı 180.

Turoğlu, H. ve Uludağ, M., (2015). Possible Hydrographic Effects of Climate Change on Lower Part of Transboundary Meriç River Basin (Turkey), Trakya University Journal of Natural Sciences, 14 (2), s. 77-85, Edirne, Türkiye. 
Türkeş, M. (2020) "Türkiye Gök Gürültülü Fırtına Ve Hortumlardan Daha Fazla Etkilenecek", https://www.researchgate.net/ publication/342709324_Turkes_M_2020_Turkiye_gok_gurultulu_firtina_ve_hortumlardan_daha_fazla_etkilenecek_ AA_2906020

UNESCO, (2007). Floods-Preparation and Prediction, World Heritage Challenges fort he Millenium, World Heritage Convention.

UNESCO, (2010). Managing Disaster Risks for World Heritage, World Heritage Convention.

Vojinovic, Z., Hammond, M., Golub, D., Hirunsalee, S., Weesakul, S., Meesuk, V., Medina, N., Sanchez, A., Kumara,S. ve Abbott M. (2016). Holistic approach to flood risk assessment in areas with cultural heritage: a practical application in Ayutthaya, Thailand. Natural Hazards, 81, s. 589-616. https://doi. org/10.1007/s11069-015-2098-7

Wang, J. (2014). Flood risk maps to cultural heritage: measures and process, Journal of Cultural Heritage, 16 (2015), s. 210220.

URL1 https://www.emdat.be/publications (Erişim: 08.10.2020)

URL2 https://www.intoflorence.com/florence-flood-novem- ber-4-1966/ (Erişim:21.10.2020)

URL3 http://cotac.global/resources/BIM4C+Disaster-Flood-Pt2. pdf (Erişim:10.10.2020)

URL4 https://www.youtube.com/watch?v=LvI6JDxjKx4 (Erişim:04.11.2020)

URL5 https://www.youtube.com/watch?v=Q63De7bXczg (Erişim:04.11.2020)

URL6 https://www.youtube.com/watch?v=JmsIRPFnpo0 (Erişim:04.11.2020)

URL7 http://gazetearsivi.milliyet.com.tr/ (Erişim: 20.12.2020)

URL8 https://www.fmglobal.com/research-and-resources/nathaz-toolkit/flood-map\# (Erişim: 05.01.2021)

URL9 https://www.kulturportali.gov.tr/turkiye/edirne/kulturenvanteri/ii--bayezid-kulliyesi (Erişim: 12.01.2021)

URL10 http://www.eskiturkiye.net/tag/edirne/ (Erişim: 07.02.2021)

URL11 https://www.muhendislikokulu.com/sozluk/sedde-nedir/ (Erişim: 04.08.2021)

URL12 https://www.arcgis.com/home/index.html (Erişim: 04.08.2021) 